Cochrane Database of Systematic Reviews

\title{
Infraorbital nerve block for postoperative pain following cleft lip repair in children (Review)
}

Feriani G, Hatanaka E, Torloni MR, da Silva EMK

Feriani G, Hatanaka E, Torloni MR, da Silva EMK.

Infraorbital nerve block for postoperative pain following cleft lip repair in children.

Cochrane Database of Systematic Reviews 2016, Issue 4. Art. No.: CD011131.

DOI: 10.1002/14651858.CD011131.pub2.

www.cochranelibrary.com 
TABLE OF CONTENTS

HEADER 1

ABSTRACT

PLAIN LANGUAGE SUMMARY

SUMMARY OF FINDINGS

BACKGROUND

OBJECTIVES

METHODS

RESULTS

Figure 1.

Figure 2.

Figure 3.

DISCUSSION

AUTHORS' CONCLUSIONS

ACKNOWLEDGEMENTS

REFERENCES

CHARACTERISTICS OF STUDIES

DATA AND ANALYSES

Analysis 1.1. Comparison 1: Infraorbital nerve block vs placebo, Outcome 1: Pain

Analysis 1.2. Comparison 1: Infraorbital nerve block vs placebo, Outcome 2: Supplemental analgesic requirements

Analysis 2.1. Comparison 2: Infraorbital nerve block vs intravenous analgesia, Outcome 1: Pain

Analysis 2.2. Comparison 2: Infraorbital nerve block vs intravenous analgesia, Outcome 2: Time to feeding

WHAT'S NEW

HISTORY

CONTRIBUTIONS OF AUTHORS 
[Intervention Review]

\section{Infraorbital nerve block for postoperative pain following cleft lip repair in children}

Gustavo Feriani ${ }^{1}$, Eric Hatanaka², Maria Regina Torloni ${ }^{3}$, Edina MK da Silva ${ }^{4}$

1Private Office, Sao Paulo, Brazil. 2Universidade Federal de São Paulo - UNIFESP, Sao Paulo, Brazil. ${ }^{3}$ Cochrane Brazil, Centro de Estudos de Saúde Baseada em Evidências e Avaliação Tecnológica em Saúde, São Paulo, Brazil. 4Emergency Medicine and Evidence Based Medicine, Universidade Federal de São Paulo, São Paulo, Brazil

Contact address: Edina MK da Silva, edinaksilva@terra.com.br.

Editorial group: Cochrane Pain, Palliative and Supportive Care Group.

Publication status and date: Stable (no update expected for reasons given in 'What's new'), published in Issue 6, 2020.

Citation: Feriani G, Hatanaka E, Torloni MR, da Silva EMK. Infraorbital nerve block for postoperative pain following cleft lip repair in children. Cochrane Database of Systematic Reviews 2016, Issue 4. Art. No.: CD011131. DOI: 10.1002/14651858.CD011131.pub2.

Copyright @ 2016 The Cochrane Collaboration. Published by John Wiley \& Sons, Ltd.

\section{A B S T R A C T}

\section{Background}

Postoperative pain is a barrier to the quality of paediatric care, the proper management of which is a challenge. Acute postoperative pain often leads to adverse functional and organic consequences that may compromise surgical outcome. Cleft lip is one of the most common craniofacial birth defects and requires surgical correction early in life. As expected after a surgical intervention in such a sensitive and delicate area, the immediate postoperative period of cleft lip repair may be associated with moderate to severe pain. Infraorbital nerve block associated with general anaesthesia has been used to reduce postoperative pain after cleft lip repair.

\section{Objectives}

To assess the effects of infraorbital nerve block for postoperative pain following cleft lip repair in children.

\section{Search methods}

We searched the following databases: Cochrane Central Register of Controlled Trials (CENTRAL, the Cochrane Library, Issue 6, 2015), MEDLINE, EMBASE, and Literatura Latino-Americana e do Caribe em Ciências da Saúde (LILACS) from inception to 17 June 2015. There were no language restrictions. We searched for ongoing trials in the following platforms: the metaRegister of Controlled Trials; ClinicalTrials.gov (the US National Institutes of Health Ongoing Trials Register), and the World Health Organization International Clinical Trials Registry Platform (on 17 June 2015). We checked reference lists of the included studies to identify any additional studies. We contacted specialists in the field and authors of the included trials for unpublished data.

\section{Selection criteria}

We included randomised controlled clinical trials that tested perioperative infraorbital nerve block for cleft lip repair in children, compared with other types of analgesia procedure, no intervention, or placebo (sham nerve block). We considered the type of drug, dosage, and route of administration used in each study. For the purposes of this review, the term 'perioperative' refers to the three phases of surgery, that is preoperative, intraoperative, and postoperative, and commonly includes ward admission, anaesthesia, surgery, and recovery.

\section{Data collection and analysis}

Two review authors (GF and EH) independently identified, screened, and selected the studies, assessed trial quality, and performed data extraction using the Cochrane Pain, Palliative and Supportive Care Review Group criteria. In case of disagreements, a third review author (EMKS) was consulted. We assessed the evidence using Grading of Recommendations, Assessment, Development and Evaluation (GRADE). 


\section{Main results}

We included eight studies involving 353 children in the review. These studies reported different types of interventions (lignocaine or bupivacaine), observation times, and forms of measuring and describing the outcomes, making it difficult to conduct meta-analyses. In the comparison of infraorbital nerve block versus placebo, there was a large effect in mean postoperative pain scores (our first primary outcome) favouring the intervention group (standardised mean difference (SMD) $-3.54,95 \%$ confidence interval (CI) -6.13 to -0.95 ; very low-quality evidence; 3 studies; 120 children). Only one study reported the duration of analgesia (in hours) (second primary outcome) with a difference favouring the intervention group (mean difference (MD) 8.26 hours, $95 \% \mathrm{Cl} 5.41$ to 11.11 ; very low-quality evidence) and less supplemental analgesic requirements in the intervention group (risk ratio (RR) $0.05,95 \% \mathrm{Cl} 0.01$ to 0.18 ; low-quality evidence). In the comparison of infraorbital nerve block versus intravenous analgesia, there was a difference favouring the intervention group in mean postoperative pain scores (SMD -1.50,95\% Cl -2.40 to -0.60; very low-quality evidence; 2 studies; 107 children) and in the time to feeding (MD -9.45 minutes, $95 \% \mathrm{Cl}-17.37$ to -1.53 ; moderate-quality evidence; 2 studies; 128 children). No significant adverse events (third primary outcome) were associated with the intervention, although three studies did not report this outcome. Five out of eight studies found no unwanted side effects after the nerve blocks. Overall, the included studies were at low or unclear risk of bias. The reasons for downgrading the quality of the evidence using GRADE related to the lack of information about randomisation methods and allocation concealment in the studies, very small sample sizes, and heterogeneity of outcome reporting.

\section{Authors' conclusions}

There is low- to very low-quality evidence that infraorbital nerve block with lignocaine or bupivacaine may reduce postoperative pain more than placebo and intravenous analgesia in children undergoing cleft lip repair. Further studies with larger samples are needed. Future studies should standardise the observation time and the instruments used to measure outcomes, and stratify children by age group.

\section{PLAIN LANGUAGE SUMMARY}

\section{Infraorbital nerve block for pain after cleft lip surgery in children}

\section{Background}

Cleft lip is one of the most common birth defects. The surgery to correct this defect can cause moderate to severe pain. Many of the drugs to reduce pain (analgesics) used in adults can have unwanted side effects in children. The treatment of the pain associated with the surgical correction of cleft lip can therefore be a challenge. One technique that can provide pain relief for these children is known as infraorbital nerve block which involves the injection of an anaesthetic around the nerve that is responsible for the sensation of touch and pain of the upper lip.

\section{Review question}

We reviewed the effectiveness of infraorbital nerve block compared with placebo ('sham' block) or other interventions for the control of pain in children having cleft lip surgery.

\section{Study characteristics}

We included eight studies with a total of 353 boys and girls, who ranged in age from 1 month to 13 years. These studies had been published up to June 2015. Three studies compared nerve block with sham block. Three studies compared nerve block with injected analgesics, and two studies compared nerve block with local anaesthesia.

\section{Key results}

The children who received the infraorbital nerve block (with lignocaine or bupivacaine) had less pain and more time between finishing surgery and needing more analgesics. These children also had less need for analgesics than those who received the sham block. The children who received the infraorbital nerve block also had less pain and were able to eat sooner than those who received injected (intravenous) analgesics. The nerve block did not appear to alter heart rate, breath rate, and blood pressure. Five out of eight studies found no unwanted side effects after the nerve blocks; the other three studies did not mention side effects.

\section{Quality of the evidence}

The overall quality of the evidence was low or very low due to the small number of children included in the studies and differences between the studies (heterogeneity) regarding the types of intervention, the observation time, and the forms of measuring and describing the outcomes. Further studies with larger numbers of children are needed. 


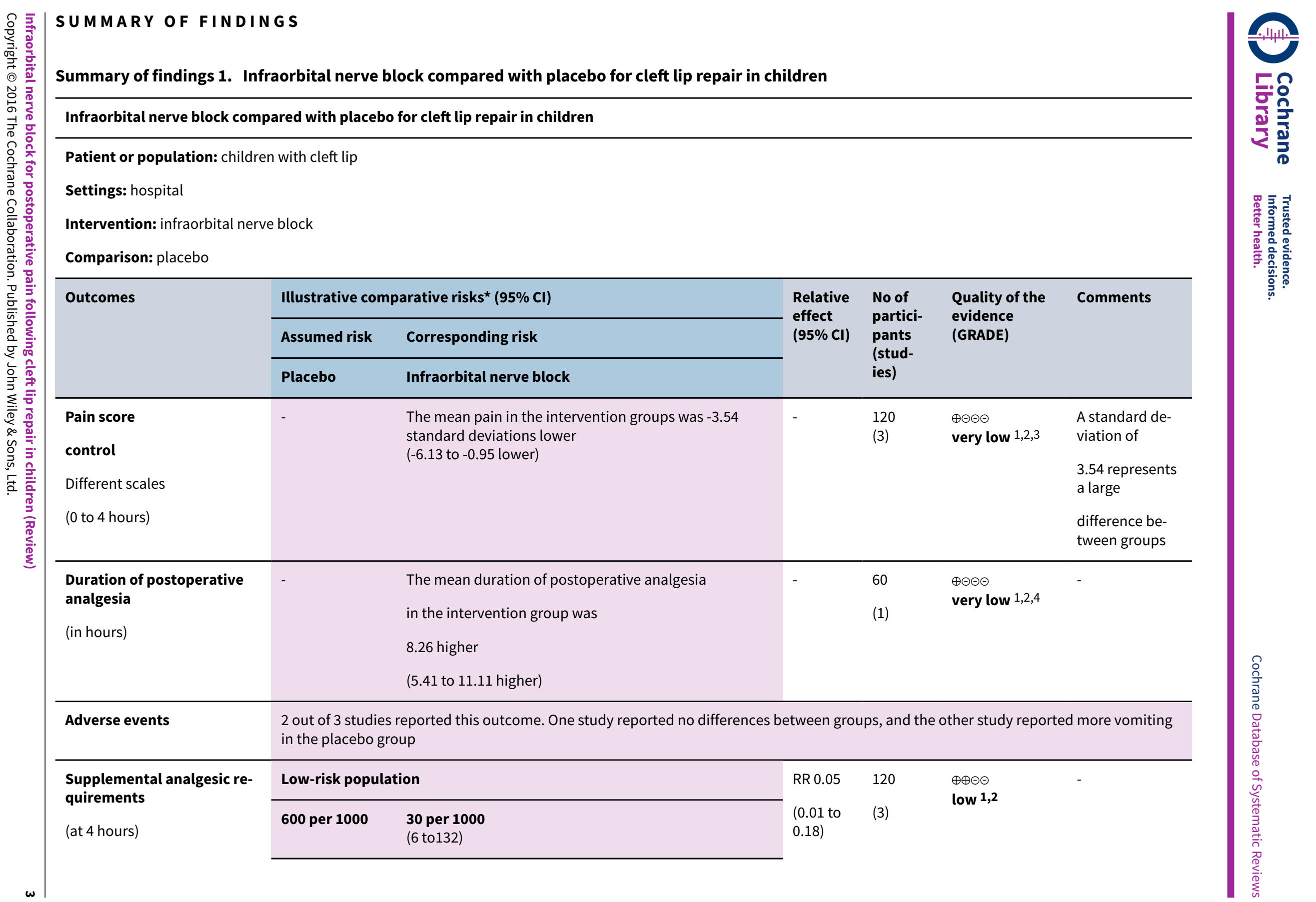


*The basis for the assumed risk (e.g. the median control group risk across studies) is provided in footnotes. The corresponding risk (and its $95 \%$ confidence interval) is based on the assumed risk in the comparison group and the relative effect of the intervention (and its $95 \% \mathrm{Cl}$ ).

Cl: confidence interval; RR: risk ratio

GRADE Working Group grades of evidence

High quality: Further research is very unlikely to change our confidence in the estimate of effect.

Moderate quality: Further research is likely to have an important impact on our confidence in the estimate of effect and may change the estimate.

Low quality: Further research is very likely to have an important impact on our confidence in the estimate of effect and is likely to change the estimate.

Very low quality: We are very uncertain about the estimate.

1Downgraded one level: few studies with small sample size.

2Downgraded one level due to risk of bias: randomisation and allocation concealment procedures were unclear.

3Downgraded one level due to inconsistency: heterogeneity in analysis.

${ }^{4}$ Downgraded one level due to uncertainty in outcome measurement.

\section{Summary of findings 2. Infraorbital nerve block compared with intravenous analgesia for cleft lip repair in children}

\section{Infraorbital nerve block compared with intravenous analgesia for cleft lip repair in children}

Patient or population: children with cleft lip

Settings: hospital

Intervention: infraorbital nerve block

Comparison: intravenous analgesia

\begin{tabular}{|c|c|c|c|c|c|c|}
\hline \multirow[t]{3}{*}{ Outcomes } & \multicolumn{2}{|c|}{ Illustrative comparative risks* $(95 \% \mathrm{CI})$} & \multirow{3}{*}{$\begin{array}{l}\text { Relative } \\
\text { effect } \\
(95 \% \mathrm{CI})\end{array}$} & \multirow{3}{*}{$\begin{array}{l}\text { No of par- } \\
\text { ticipants } \\
\text { (studies) }\end{array}$} & \multirow{3}{*}{$\begin{array}{l}\text { Quality of the } \\
\text { evidence } \\
\text { (GRADE) }\end{array}$} & \multirow[t]{3}{*}{ Comments } \\
\hline & Assumed risk & Corresponding risk & & & & \\
\hline & $\begin{array}{l}\text { Intravenous } \\
\text { analgesia }\end{array}$ & Infraorbital nerve block & & & & \\
\hline
\end{tabular}




\begin{tabular}{|c|c|c|c|c|c|c|c|}
\hline \multicolumn{2}{|r|}{$\begin{array}{l}\text { Pain score } \\
\text { control } \\
\text { Different scales } \\
\text { (0 to } 4 \text { hours) }\end{array}$} & - & $\begin{array}{l}\text { The mean pain in the intervention groups was } \\
-1.5 \text { standard deviations lower } \\
\text { (-2.4 to }-0.6 \text { lower) }\end{array}$ & - & $\begin{array}{l}107 \\
(2)\end{array}$ & $\begin{array}{l}\oplus \odot \odot \odot \\
\text { very low } \mathbf{1 , 2 , 3}\end{array}$ & $\begin{array}{l}\text { A standard devia- } \\
\text { tion of } \\
1.5 \text { represents a } \\
\text { large } \\
\text { difference be- } \\
\text { tween groups }\end{array}$ \\
\hline $\begin{array}{l}\overrightarrow{0} \\
\stackrel{0}{0} \\
\stackrel{0}{\overline{0}} \stackrel{0}{0}\end{array}$ & $\begin{array}{l}\text { Duration of postoperative } \\
\text { analgesia }\end{array}$ & \multicolumn{6}{|c|}{ This outcome was not reported } \\
\hline 离 & Adverse events & \multicolumn{6}{|c|}{2 out of 3 studies reported this outcome. Both studies reported no difference between groups } \\
\hline 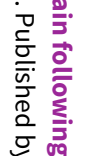 & $\begin{array}{l}\text { Supplemental analgesic re- } \\
\text { quirements }\end{array}$ & 634 per 1000 & $\begin{array}{l}\mathbf{1 7 1} \text { per } 1000 \\
(82 \text { to } 349)\end{array}$ & $\begin{array}{l}\text { RR } 0.27 \\
(0.13 \text { to } \\
0.55)\end{array}$ & $\begin{array}{l}82 \\
(1)\end{array}$ & $\begin{array}{l}\oplus \ominus \odot \odot \\
\text { very low } \mathbf{1 , 2 , 4}\end{array}$ & - \\
\hline 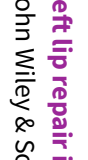 & $\begin{array}{l}\text { Time to feeding after } \\
\text { surgery }\end{array}$ & - & $\begin{array}{l}\text { The mean time to feeding in the intervention group } \\
\text { was } 9.45 \text { lower } \\
\text { (17.37 to } 1.53 \text { lower) }\end{array}$ & - & $\begin{array}{l}128 \\
(2)\end{array}$ & $\begin{array}{l}\oplus \oplus \ominus \ominus \\
\text { low 1,2 }\end{array}$ & - \\
\hline 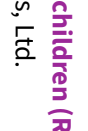 & \multicolumn{7}{|c|}{$\begin{array}{l}\text { *The basis for the assumed risk (e.g. the median control group risk across studies) is provided in footnotes. The corresponding risk (and its } 95 \% \text { confidence interval) is } \\
\text { based on the assumed risk in the comparison group and the relative effect of the intervention (and its } 95 \% \mathrm{CI} \text { ). } \\
\text { Cl: confidence interval; RR: risk ratio }\end{array}$} \\
\hline$\sum_{\Sigma}^{\infty}$ & \multicolumn{7}{|c|}{$\begin{array}{l}\text { GRADE Working Group grades of evidence } \\
\text { High quality: Further research is very unlikely to change our confidence in the estimate of effect. } \\
\text { Moderate quality: Further research is likely to have an important impact on our confidence in the estimate of effect and may change the estimate. } \\
\text { Low quality: Further research is very likely to have an important impact on our confidence in the estimate of effect and is likely to change the estimate. } \\
\text { Very low quality: We are very uncertain about the estimate. }\end{array}$} \\
\hline
\end{tabular}

1Downgraded one level: few studies with small sample size.

2Downgraded one level due to risk of bias: randomisation and allocation concealment procedures were unclear.

${ }^{3}$ Downgraded one level due to inconsistency: heterogeneity in analysis.

${ }^{4}$ Downgraded one level due to uncertainty in outcome measurement.

\section{Summary of findings 3. Infraorbital nerve block compared with infiltration of the incision for cleft lip repair in children}

\section{Infraorbital nerve block compared with infiltration of the incision for cleft lip repair in children}

Patient or population: children with cleft lip 


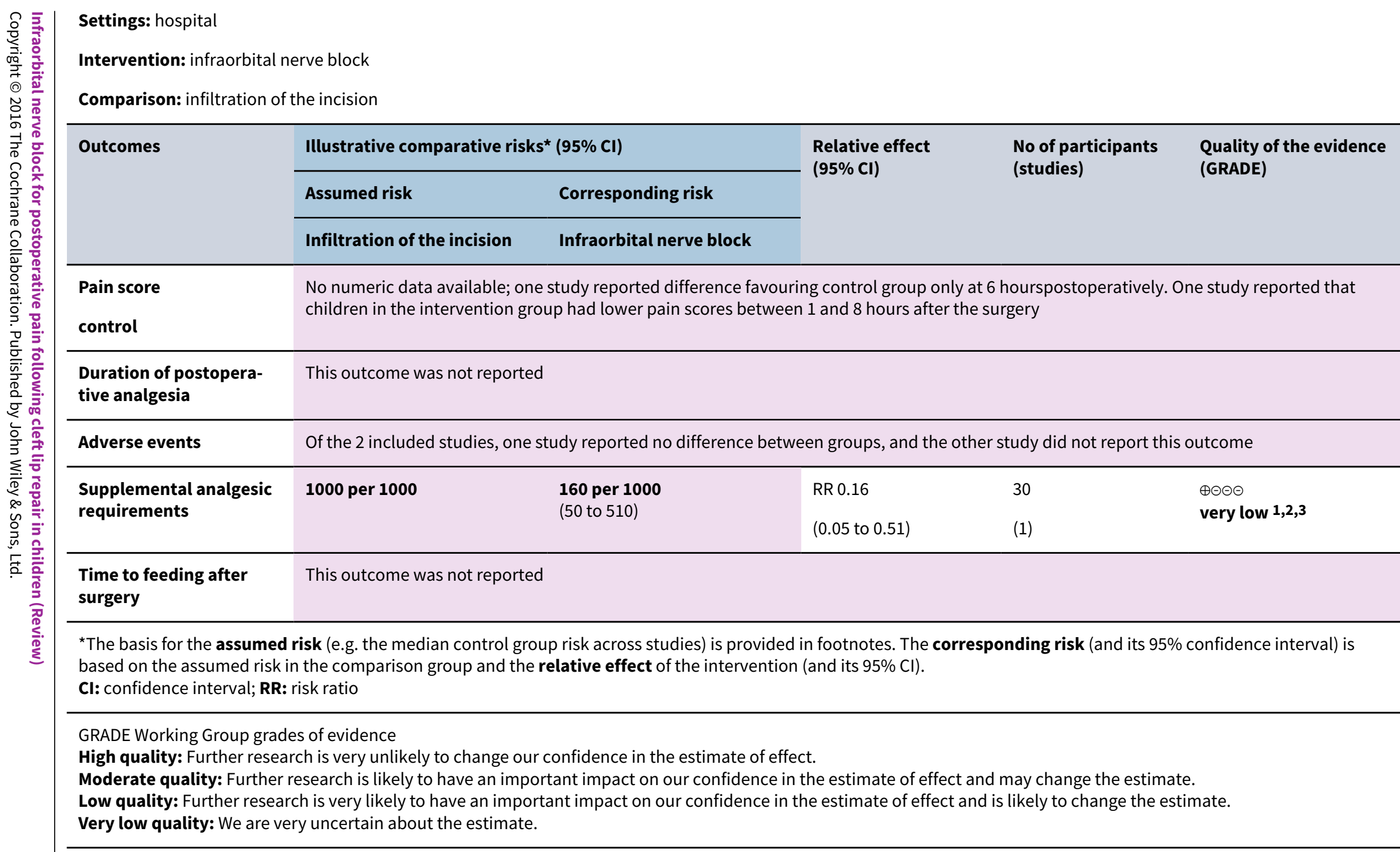

1Downgraded one level: few studies with small sample size.

2Downgraded one level due to risk of bias: randomisation and allocation concealment procedures were unclear.

3Downgraded one level due to uncertainty in outcome measurement. 


\section{B A C K G R O U N D}

\section{Description of the condition}

Postoperative pain is a barrier to quality of paediatric care, the proper management of which is a challenge. Acute pain often leads to adverse functional and organic consequences that may compromise surgical outcome. During the postoperative period, acute pain can also lead to psychological, cardiorespiratory, and metabolic repercussions (Helgadóttir 2000). Cleft lip is one of the most common craniofacial birth defects and requires surgical correction early in life (Arosarena 2007).

The connective tissue and skeleton of the face form during the third week of embryonic life by the migration of neural crest cells. Cleft lip is caused by failure in the fusion of the frontonasal and maxillary processes, which take place between the fourth and eighth weeks of embryonic development (Shkoukani 2013). The abnormal sequence of lip development can lead to abnormal positioning of the tongue and affect palatal development. Although often associated, cleft lip and palate are different malformations, both embryologically and aetiologically. Cleft lip may be part of a genetic syndrome or be associated with other birth defects (Sykes 2005). Orofacial clefting is estimated to affect 1 in 500 to 700 live births. It is more frequent in Asians and Native Americans and in boys (60\% to $80 \%$ ) (WHO 2004). Cleft lip is associated with cleft palate in $68 \%$ to $86 \%$ of cases (Arosarena 2007).

Cleft lip and palate are not associated with genetic syndromes in $70 \%$ of cases. Genetic predisposition, environmental factors, and teratogenic agents (for example maternal smoking, zinc and folate deficiency, alcohol, pesticides, chemical solvents, antiepileptic drugs, etc.) have been investigated as potential causes or risk factors for orofacial clefts (Mossey 2009). It is possible to identify cleft lip on prenatal ultrasounds, starting at approximately 18 weeks' gestation, although sensitivity is still low, especially on two-dimensional ultrasound. In cases of suspected cleft lip on ultrasound, the patient should be seen by maternal-foetal specialists, and genetic counselling is recommended (Gagnon 2009).

The varied morphology of facial clefts, which may involve four different structures (the upper lip, alveolar process, hard and soft palate) and the possibility of unilateral or bilateral, complete or incomplete involvement, are challenges to the creation of a single classification (Rodriguez 2001). Regardless of the extension of the clefts, early surgical repair must be planned to minimise physical, psychological, and social consequences. Affected individuals may have feeding and speech problems, in addition to increased risks of middle ear infections. The condition is associated with increased mortality from many causes, and the aesthetic defect may cause social rejection and decreased quality of life (Law 2002; Shkoukani 2013).

Surgical correction of cleft lip can be performed during the neonatal period or later. The ideal period for surgery depends on the severity of the deformity, the child's health, and other factors that may influence the efficacy and safety of the procedure (Shkoukani 2013). There is a consensus that the correction should be carried out as early as possible, and it is often performed between the third and sixth months of life (Delgado 2005; Sykes 2005). The management of cleft lip involves a multidisciplinary team to ensure comprehensive care including functional and aesthetic issues. There are several different treatment plans for the surgical correction of the deformity (Mathes 2006).

As expected after a surgical intervention in such a sensitive and delicate area, the immediate postoperative period of cleft lip repair may be associated with moderate to severe pain (Augsornwan 2008; Biazon 2008). This pain requires adequate analgesia to prevent the child from becoming agitated and touching the surgical site which could disrupt the wound-healing process and compromise the aesthetic results as well as extend the time of hospitalisation.

\section{Description of the intervention}

Treatment of acute postoperative pain usually involves the use of non-steroidal anti-inflammatory drugs (NSAIDs), analgesics, and oral or intravenous opioids, which may be associated with adverse events such as nausea and vomiting, drowsiness, and respiratory depression. These treatments are frequently underutilised in children due to safety concerns and lack of experience in pain management (Jonnavithula 2007). Another option to control postoperative pain is the injection of local anaesthesia into the surgical incision, but the procedure may distort the margins of the cleft and interfere with the aesthetic repair (Prabhu 1999). In the last two decades there has been a growing interest in regional anaesthesia for paediatric surgical procedures. Several techniques have been evaluated and tested in several types of paediatric surgery, including cleft lip repair (Gaonkar 2004; Jonnavithula 2007; Simion 2008; Takmaz 2009).

Infraorbital nerve block associated with general anaesthesia has been used to reduce postoperative pain after cleft lip repair. The infraorbital nerve is the terminal branch of the second division of the trigeminal nerve, which differentiates into the infraorbital nerve after entering the ocular area through the inferior orbital fissure. It emerges through the infraorbital foramen, dividing into four branches (inferior palpebral, external nasal, internal nasal, and superior labial), innervating the skin of the upper cheek, the mucous membrane of the maxillary sinus, the incisor, canine and premolar teeth, upper gums, skin and conjunctiva of the lower eyelid, part of the nose, skin and mucosa of the upper lip (Simion 2008).

\section{How the intervention might work}

Infraorbital nerve block is performed by injecting an anaesthetic into the infraorbital foramen, either intra- or extraorally (percutaneous). In the percutaneous approach, the infraorbital foramen is identified as a point halfway between the midpoint of palpebral fissure and the angle of the mouth, approximately 7.5 $\mathrm{mm}$ from the alar base; a needle is then introduced perpendicular to the skin and advanced until bone resistance is felt. The needle is withdrawn slightly, and after a negative aspiration test for blood, the local anaesthetic is injected (Bosenberg 1995; Takmaz 2009). For intraoral infraorbital nerve block, a finger marks the approximate point of the infraorbital foramen externally, as described above, then the lip is everted and the needle is inserted into the mucobuccal fold above the second premolar toward the infraorbital foramen (Jonnavithula 2007). The injected anaesthetic blocks the generation and propagation of impulses in excitable tissues by blocking sodium channels in the cell receptors. The absence of this ion prevents the transmission of pain sensitivity which results in effective regional blockage of pain when these 
drugs are deposited near peripheral nerves, nerve roots, or the spinal cord. The effect of this process depends on the dose, concentration, and type of anaesthetic used (Strichartz 1976).

\section{Why it is important to do this review}

There are several procedures to control acute postoperative pain associated with cleft lip repair to ensure the comfort of the child and to preserve the integrity of the delicate surgical site. Infraorbital nerve block is frequently used because it can provide long-lasting pain relief and avoid the complications associated with pain relief drugs. There is a need to assess and synthesise the evidence available so far on the effectiveness and safety of this procedure.

\section{OB JECTIVES}

To assess the effects of infraorbital nerve block for postoperative pain following cleft lip repair in children.

\section{METHODS}

\section{Criteria for considering studies for this review}

\section{Types of studies}

We included all randomised, published or unpublished, controlled clinical studies that tested perioperative infraorbital nerve block for cleft lip repair in children compared with other types of analgesia procedures, no intervention, or placebo.

\section{Types of participants}

We included children up to 13 years of age, undergoing cleft lip repair surgery.

\section{Types of interventions}

Perioperative infraorbital nerve block compared with another intervention (that is intravenous analgesia, peri-incisional infiltration), no intervention, or placebo. We considered the type of drug, dosage, and route of administration used in each study. For the purposes of this review, the term perioperative refers to the three phases of surgery: preoperative, intraoperative, and postoperative, and commonly includes ward admission, anaesthesia, surgery, and recovery.

\section{Types of outcome measures}

\section{Primary outcomes}

1. Pain measured by valid instruments (e.g. Neonatal Infant Pain Scale (NIPS) (Hudson-Barr 2002); the Face, Legs, Activity, Cry, Consolability (FLACC) Scale (Merkel 1997))

2. Duration of postoperative analgesia

3. Adverse events

\section{Secondary outcomes}

1. Need for analgesic prescription for pain

2. Time to first analgesic requirement

3. Heart rate, respiratory rate, and blood pressure

4. Time to feeding after surgery

5. Duration of hospitalisation

\section{Search methods for identification of studies}

\section{Electronic searches}

We searched the following databases:

- Cochrane Central Register of Controlled Trials (CENTRAL, the Cochrane Library, Issue 6, 2015);

- MEDLINE (OVID) 1946 to 17 June 2015;

- EMBASE (OVID) 1974 to 17 June 2015;

- Literatura Latino-Americana e do Caribe em Ciências da Saúde (LILACS) from inception to 17 June 2015.

The search strategies for MEDLINE, EMBASE, LILACS, and CENTRAL are presented in Appendix 1; Appendix 2; Appendix 3; Appendix 4.

\section{Searching other resources}

We searched for ongoing trials in the following sites: the metaRegister of Controlled Trials (www.controlled-trials.com); ClinicalTrials.gov (the US National Institutes of Health Ongoing Trials Register) (www.clinicaltrials.gov), and the World Health Organization International Clinical Trials Registry Platform (www.who.int/trialsearch) (last search performed in 17 June 2015).

We checked the reference lists of the included studies to identify any additional studies. We contacted specialists in the field and authors of the included trials for unpublished data. We did not impose any language restrictions.

\section{Data collection and analysis}

\section{Selection of studies}

Two review authors (GF and EH) independently screened the trials identified by the literature search. After merging the search results and eliminating duplicate records, the review authors examined the titles and abstracts to identify relevant reports and then retrieved and examined the full text of these reports for compliance with eligibility criteria. The review authors documented the reasons for exclusion of individual trials and consulted a third review author (EMKS) in case of disagreement, not including data from trials under scrutiny until a consensus was reached. They used the PRISMA flow chart diagram to document the screening process (Liberati 2009).

\section{Data extraction and management}

Two review authors (GF and EH) independently extracted data using a standard form and entered data into Review Manager (RevMan 2014). They resolved disagreements by consensus or by discussion with a third review author (EMKS). Review authors extracted the following information from each study: characteristics of the study (design, setting); participants; type of surgery; interventions; outcomes (outcome measures, timing of outcomes, adverse events); and risk of bias. Where studies had multiple publications, we used the main trial report as the reference and supplemented it with additional details from secondary papers. We contacted the authors of all studies that did not provide complete information.

\section{Assessment of risk of bias in included studies}

We used the Oxford Quality Score to assess the methodological quality of included studies (Jadad 1996). We assessed the included studies using Cochrane's tool for assessing risk of bias 
(Higgins 2011). We analysed the following domains: sequence generation, allocation concealment, blinding, incomplete outcome data, selective outcome reporting, sample size and other issues (for example extreme baseline imbalance). Two review authors independently assessed the risk of bias, resolving any disagreements by consensus or by discussion with a third review author. We categorised each domain as being at 'low risk' of bias, 'high risk' of bias, or 'unclear risk' of bias (either lack of information or uncertainty over the potential for bias). We completed a 'Risk of bias' table for each eligible study and presented the assessment using a 'Risk of bias' summary figure, which displays all of the judgements in a cross-tabulation of study by entry. This display of internal validity indicates the weight the reader may give to the results of each study. We included all randomised controlled trials that met the inclusion criteria in the review, regardless of the risk of bias. In future updates, when appropriate, we will perform sensitivity analysis to evaluate the effect of including studies at high risk of bias.

\section{Measures of treatment effect}

For dichotomous variables, we calculated the risk ratio and $95 \%$ confidence intervals (Cls). For continuous data, we calculated mean differences and $95 \% \mathrm{Cls}$ between treatment groups if studies reported exactly the same outcomes. If similar outcomes were reported on different scales, we calculated the standardised mean difference and $95 \% \mathrm{Cl}$. If different scales measuring the same outcome increased with the symptom severity whilst others decreased with it, we subtracted the mean from the maximum possible value for the scale to ensure that all the scales pointed in the same direction. The most appropriate way of summarising time-to-event data is to use methods of survival analysis and to express the intervention effect as a hazard ratio, and we planned to obtain these data directly from the results of the studies (Higgins 2011).

\section{Unit of analysis issues}

The unit of analysis was the individual child (unit to be randomised for interventions to be compared), that is the number of observations in the analysis should match the number of children randomised.

\section{Dealing with missing data}

We contacted the study authors for additional information about any missing or unavailable data. In the case of no response, irrespective of the type of data, we reported drop-out rates in the 'Characteristics of included studies' tables of the review, and used intention-to-treat analyses (Higgins 2011). Only one author replied and sent us the information requested (Rajamani 2007).

\section{Assessment of heterogeneity}

We qualified inconsistency among the pooled estimates using the $\mathrm{I}^{2}$ statistic: $((\mathrm{Q}-\mathrm{df}) / \mathrm{Q}) \times 100 \%$ test, where $\mathrm{Q}$ is the $\mathrm{Chi}^{2}$ statistic and $\mathrm{df}$ represents the degree of freedom. This examines the percentage of total variation across studies due to heterogeneity rather than chance. We used a fixed-effect model in the absence of substantial heterogeneity $\left(\mathrm{I}^{2}<50 \%\right)$, otherwise we used a random-effects model $\left(I^{2}>50 \%\right.$ ) (Higgins 2011).

\section{Data synthesis}

Methods of synthesising the studies depended on quality, design, and heterogeneity. We explored both clinical and statistical heterogeneity. In the absence of clinical and statistical heterogeneity $\left(I^{2}<50 \%\right)$ we used a fixed-effect model to pool the data. In the presence of statistical heterogeneity $\left(1^{2}>50 \%\right)$ we used a random-effects model for meta-analysis. Where synthesis was inappropriate, we presented a narrative overview. We applied the Grading of Recommendations Assessment, Development and Evaluation (GRADE) approach to assess overall quality of evidence for each outcome that included pooled results from meta-analysis (GRADEpro GDT 2015).

\section{Subgroup analysis and investigation of heterogeneity}

In case of substantial heterogeneity and if there were sufficient data, we planned to investigate the possible causes for the heterogeneity by further exploring the impact of the condition of the children and interventions (that is participant characteristics, type and duration of the surgery, type and doses of drugs, adjuvant drugs) using subgroup analyses. However, this was not possible for this review.

\section{Sensitivity analysis}

If the number of studies was sufficient, we planned to perform sensitivity analyses separating studies according to risk of bias. We planned do this by excluding the trials most susceptible to bias based on our 'Risk of bias' assessment: those with inadequate allocation concealment; high levels of postrandomisation losses or exclusions; and uncertain or unblinded outcome assessment (Deeks 2011). However, it was not possible to perform sensitivity analyses due to the small number of included studies.

\section{Presentation of results}

We presented the main results of the review in a Summary of findings 1 using the GRADE approach (GRADEpro GDT 2015), which provides key information concerning the quality of the evidence, the magnitude of effect of the interventions examined, and the sum of available data on the main outcomes, as recommended by Cochrane (Schünemann 2011).

\section{RESULTS}

\section{Description of studies}

\section{Results of the search}

The search strategy (last run on 17 June 2015) retrieved 106 records: CENTRAL 12 references; MEDLINE (OVID) 25 references; EMBASE (OVID) 29 references; and LILACS 40 references. We did not identify any unpublished studies. After exclusion of duplicates, 83 records remained. We examined the titles and abstracts of these references and selected 12 potentially relevant studies for full-text reading. Eight fulfilled the selection criteria and were included in the review (Ahuja 1994; Delgado 2005; Gaonkar 2004; Nicodemus 1991; Prabhu 1999; Rajamani 2007; Simion 2008; Takmaz 2009), and four did not and were excluded (Grewal 2015; Jindal 2011; Jonnavithula 2007; Mane 2011. The process of study identification and selection is depicted in Figure 1. 
Figure 1. Study flow diagram.

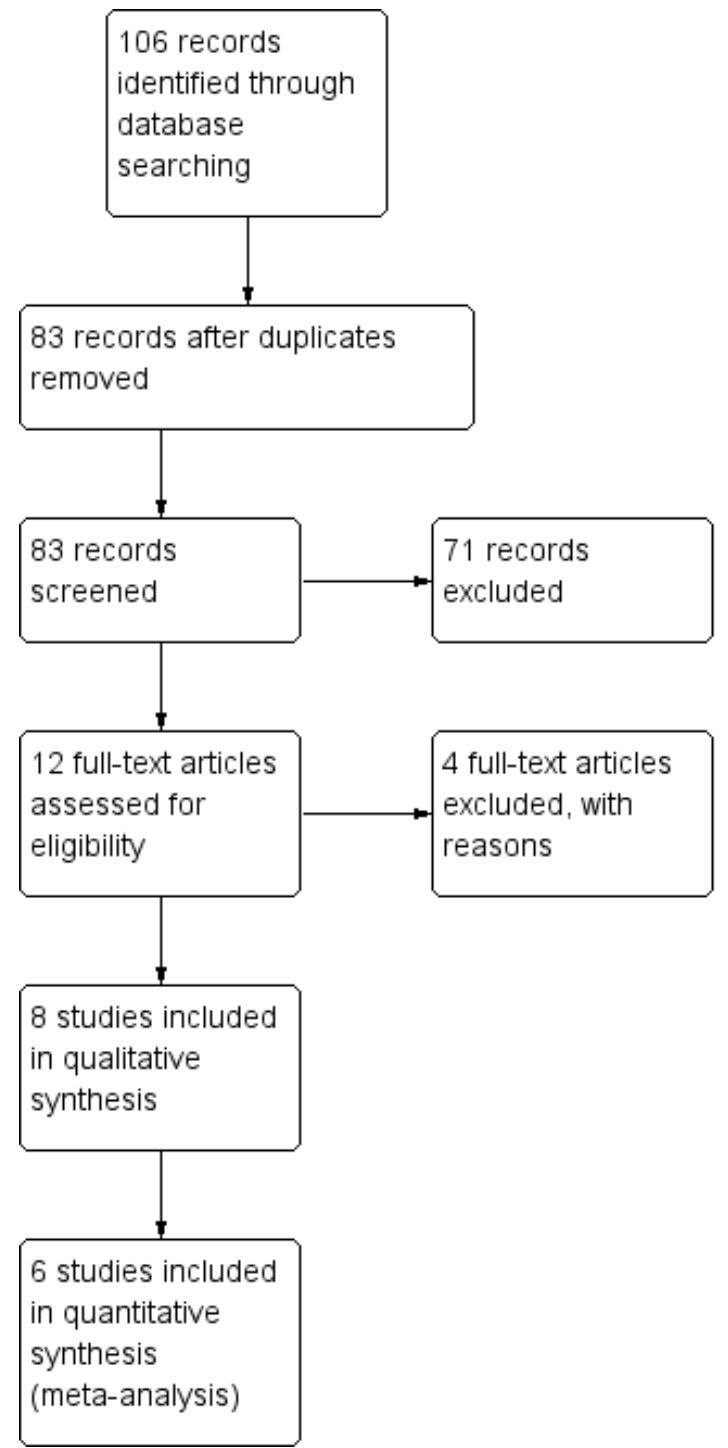

\section{Included studies}

We included eight studies (Ahuja 1994; Delgado 2005; Gaonkar 2004; Nicodemus 1991; Prabhu 1999; Rajamani 2007; Simion 2008; Takmaz 2009). Three compared infraorbital nerve block with placebo, that is sham block (Ahuja 1994; Nicodemus 1991; Takmaz 2009). Three studies compared infraorbital nerve block with intravenous analgesia (Delgado 2005; Rajamani 2007; Simion 2008), and two studies compared infraorbital nerve block with anaesthetic infiltration of the incision (Gaonkar 2004; Prabhu 1999).

\section{Design}

All included studies were prospective, randomised, controlled, and double-blind trials conducted in a single centre.

\section{Sample sizes}

The eight studies included a total of 353 children; sample sizes ranged from 20 to 82 children per study.

\section{Setting}

All eight studies were conducted in hospitals. Seven were conducted exclusively by anaesthesiologists, and one involved the department of anaesthesiology and plastic and reconstructive surgery (Takmaz 2009). Four studies were carried out in India (Ahuja 1994; Gaonkar 2004; Prabhu 1999; Rajamani 2007), two in the United States (Nicodemus 1991; Simion 2008), one in Turkey (Takmaz 2009), and one in Spain (Delgado 2005).

\section{Participants}

Participants were children of both genders. Three studies included only children under one year of age (Ahuja 1994; Delgado 2005; Simion 2008). Takmaz 2009 and Prabhu 1999 included children under two years of age. Rajamani 2007 included children under 10 years of age. Nicodemus 1991 included children up to 13 years of age. Although our review had established 10 years of age as a limit, we decided not to exclude this last study because it likely included few children over this age limit, as the authors reported that the mean age (standard deviation) of the intervention and placebo groups were 7.47 (3.68) years and 6.20 (3.59) years, respectively. 


\section{Intervention}

Three articles compared infraorbital nerve block with placebo; Ahuja 1994 applied $1 \mathrm{ml}$ of $1 \%$ lignocaine with adrenaline (1:400,000); Nicodemus 1991 used 1 to $1.5 \mathrm{ml}$ of $0.5 \%$ bupivacaine with epinephrine (1:200,000); and Takmaz 2009 applied $1.5 \mathrm{ml}$ $0.25 \%$ bupivacaine.

Delgado 2005 compared infraorbital nerve block with 1 to $2 \mathrm{ml}$ of $0.25 \%$ bupivacaine with adrenaline and intravenous $1.5 \mathrm{mg} / \mathrm{kg}$ of tramadol. Rajamani 2007 compared $1 \mathrm{ml}$ of $0.25 \%$ bupivacaine with $2 \mu \mathrm{g} / \mathrm{kg}$ of intravenous fentanyl, and Simion 2008 compared $0.5 \mathrm{ml}$ of $0.25 \%$ bupivacaine and $2 \mu \mathrm{g} / \mathrm{kg}$ of intravenous fentanyl.

Gaonkar 2004 compared $1 \mathrm{ml} 0.25 \%$ bupivacaine with adrenaline (1:200,000), and Prabhu 1999 compared $2 \mathrm{ml}$ of $0.125 \%$ bupivacaine with the same doses of anaesthetic infiltration in the margin of the incision.

\section{Outcomes}

All included studies assessed pain as one of their outcomes but used different measurement scales. Only one study reported

\section{Figure 2. Risk of bias graph: review authors' judgements about each risk of bias item presented as percentages} across all included studies.

Random sequence generation (selection bias)

Allocation concealment (selection bias)

Blinding of participants and personnel (performance bias): All outcomes

Blinding of outcome assessment (detection bias): All outcomes Incomplete outcome data (attrition bias): All outcomes

Selective reporting (reporting bias)

Other bias

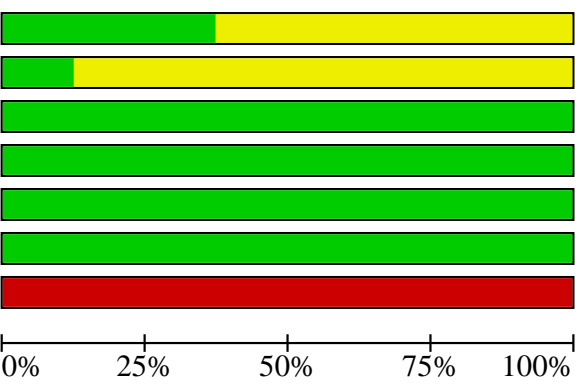

Low risk of bias

$\square$ Unclear risk of bias
High risk of bias 
Figure 3. Risk of bias summary: review authors' judgements about each risk of bias item for each included study.

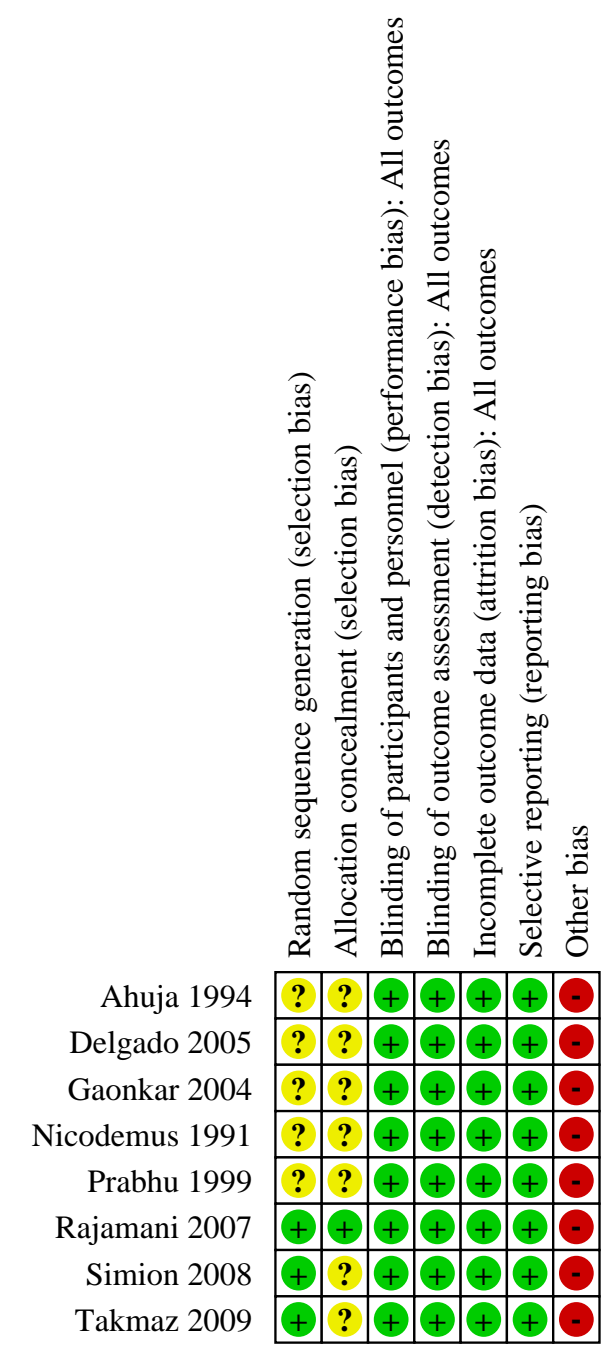

\section{Allocation}

We assessed the included studies on the method used to generate the allocation sequence, and categorised the method as low risk of bias (any truly random process, for example random number table; computer random number generator); unclear risk of bias (method used to generate sequence not clearly stated); or high risk of bias (any non-random process, for example odd or even date of birth; hospital or clinic record number). Only three studies reported the method of randomisation (Rajamani 2007; Simion 2008; Takmaz 2009), and these were classified as having a low risk of bias for this domain. We classified the other five studies as having an unclear risk of bias for random sequence generation.

We assessed the included studies on the method used to conceal allocation to interventions prior to assignment and whether intervention allocation could have been foreseen in advance of or during recruitment, or changed after assignment. We categorised the method as: low risk of bias (for example telephone or

central randomisation; consecutively numbered, sealed, opaque envelopes); unclear risk of bias (method not clearly stated); or high risk of bias (open random allocation; unsealed or non-opaque envelopes). We classified seven studies as having an unclear risk of bias for allocation concealment because they provided no information on this. Only one study reported the randomisation and allocation concealment method and was assessed as low risk of bias (Rajamani 2007).

\section{Blinding}

For each included study we assessed the methods used, if any, to blind study participants and personnel from knowledge of which intervention a child received. We considered studies to be at low risk of bias if they were blinded, unclear risk of bias when the method was not clearly stated, and high risk of bias when they were not blinded. All eight studies were double blinded, with low risk of performance and detection bias. 


\section{Incomplete outcome data}

We assessed the included studies for the completeness of data including attrition and exclusions from the analysis. We categorised the domain as: low risk of bias (for example no missing outcome data; missing outcome data balanced across groups); high risk of bias (for example numbers or reasons for missing data imbalanced across groups; 'as treated' analysis done with substantial departure of intervention received from that assigned at randomisation); and unclear risk of bias (not clearly stated). None of the included studies reported losses and were all therefore classified as having a low risk of attrition bias.

\section{Selective reporting}

We assessed the possibility of selective outcome reporting bias and classified the studies as low risk of bias (where it was clear that all of the study's prespecified outcomes and all expected outcomes of interest to the review were reported); high risk of bias (where not all the study's prespecified outcomes were reported; one or more reported primary outcomes was not prespecified; outcomes of interest are reported incompletely and so cannot be used; study fails to include results of a key outcome that would have been expected to have been reported); and unclear risk of bias (not clearly stated). We judged all included studies to be at low risk for selective reporting bias.

\section{Other potential sources of bias}

We assessed possible bias by small size of the included studies, as small studies have been shown to overestimate treatment effects, allowing critical criteria to be compromised. We considered studies to be at low risk of bias if they had 200 children or more per arm, at unclear risk if they had 50 to 200 children, and at high risk if they had fewer than 50 children (Dechartres 2013; Nüesch 2010). We therefore judged all studies to be at high risk of bias.

\section{Effects of interventions}

See: Summary of findings 1 Infraorbital nerve block compared with placebo for cleft lip repair in children; Summary of findings 2 Infraorbital nerve block compared with intravenous analgesia for cleft lip repair in children; Summary of findings 3 Infraorbital nerve block compared with infiltration of the incision for cleft lip repair in children

The eight included studies reported different types of interventions, observation times, and forms of measuring and describing the outcomes, making it difficult to pool their data. We therefore performed a few meta-analyses, but have presented mostly narrative descriptions of the outcomes for each comparison. See: Summary of findings 1 , Summary of findings 2 and Summary of findings 3 .

\section{Infraorbital nerve block versus placebo}

Three of the studies compared infraorbital nerve block to placebo (Ahuja 1994; Nicodemus 1991; Takmaz 2009).

\section{Primary outcomes}

\section{Pain measured by valid instruments}

The meta-analysis of the three studies that reported this outcome showed a significant difference in favour of the intervention group in the peak of pain, measured during the postoperative period (standardised mean difference (SMD) -3.54, 95\% confidence interval $(\mathrm{Cl})-6.13$ to $-0.95 ; 3$ studies; 120 children; $\mathrm{P}=0.007 ; \mathrm{I}^{2}=$ $94 \%)$. There was significant heterogeneity in this analysis, and the random-effects model was used (Analysis 1.1). After we excluded one study (Takmaz 2009), heterogeneity disappeared (SMD -1.80 , $95 \% \mathrm{Cl}-2.33$ to $-1.27 ; 2$ studies; 80 children; $\mathrm{P}<0.00001 ; \mathrm{I}^{2}=0 \%$ ). This outcome was downgraded three levels of evidence (to very low quality) due to few studies with a limited number of children, unclear methodology of the studies, and the heterogeneity of analysis.

\section{Duration of postoperative analgesia}

In Nicodemus 1991, the intervention group had a significantly longer duration of analgesia than the placebo group: $19.43 \pm 5.06$ hours versus $11.17 \pm 6.16$ hours (mean difference (MD) $8.26,95 \% \mathrm{Cl}$ 5.41 to $11.11 ; \mathrm{P}<0.00001)$.

\section{Adverse events}

Ahuja 1994 reported no adverse events in the children. Takmaz 2009 reported more episodes of vomiting in the placebo than in the intervention group (40\% versus $10 \%$; $=0.001)$. Nicodemus 1991 did not report this outcome.

\section{Secondary outcomes}

\section{Need for analgesic prescription for pain}

Three studies reported this outcome (Ahuja 1994; Nicodemus 1991; Takmaz 2009). There was a significant difference, with more supplemental analgesic required by the children in the placebo group compared with the intervention group (risk ratio (RR) 0.05 , $95 \% \mathrm{Cl} 0.01$ to 0.18 ; 3 studies; 120 children; $\mathrm{P}<0.0001 ;\left.\right|^{2}=19 \%$ ) (Analysis 1.2). We classified this outcome as low-quality evidence, with one level of downgrading due to the small number of children and unclear methodology of the studies.

\section{Time to first analgesic requirement}

Takmaz 2009 reported that the time to first analgesic requirement (defined as the time from arrival in the recovery room until the administration of any rescue analgesic) was significantly longer in the intervention compared with the placebo group ( $8.3 \pm 0.9$ hours versus $1.6 \pm 0.8$ hours; $\mathrm{P}=0.001$ ).

\section{Heart rate, respiratory rate, and blood pressure}

Ahuja 1994 reported no significant difference in heart rate, respiratory rate, and blood pressure between the groups. Takmaz 2009 reported no differences in the respiratory rate and blood pressure between groups, but the children in the placebo group had significantly higher heart rates than those in the intervention group.

\section{Time to feeding after surgery}

None of the included reported this outcome.

\section{Duration of hospitalisation}

None of the included studies reported this outcome.

\section{Infraorbital nerve block versus intravenous analgesia}

Three studies compared infraorbital nerve block and intravenous analgesia (Delgado 2005; Rajamani 2007; Simion 2008). 


\section{Primary outcomes}

\section{Pain measured by valid instruments}

The meta-analysis of two studies, Delgado 2005 and Rajamani 2007, showed a significant difference between the groups favouring the intervention group in mean peak pain measured in the first four hours after surgery (SMD $-1.50,95 \% \mathrm{Cl}-2.40$ to $-0.60 ; 2$ studies; 107 children; $P=0.001 ; I^{2}=64 \%$ ) (Analysis 2.1). Simion 2008 stated that there were no differences between the groups (only graphic available), but the observation was made only one hour after surgery. This outcome was downgraded three levels to very low-quality evidence due to few studies with a limited number of children, unclear methodology of the studies, and heterogeneity.

\section{Duration of postoperative analgesia}

None of the included studies reported this outcome.

\section{Adverse events}

No adverse events attributable to either analgesic technique were reported by Rajamani 2007 or Simion 2008. Delgado 2005 did not report this outcome.

\section{Secondary outcomes}

\section{Need for analgesic prescription for pain}

In Rajamani 2007 more children required rescue analgesics in the control group than in the intervention group ( $\mathrm{RR} 0.27,95 \% \mathrm{Cl} 0.13$ to $0.55 ; \mathrm{P}<0.001)$.

\section{Time to first analgesic requirement}

It was not possible perform meta-analysis of this outcome as planned due to the lack of necessary data in the included studies. Delgado 2005 reported that the time to first analgesic requirement (defined as the time from arrival in the recovery room until the administration of any rescue analgesic) was longer in the infraorbital block group $(7.3 \pm 5.1$ hours) compared with the intravenous analgesia $(2.8 \pm 2.2$ hours $)(P<0.01)$. Moreover, Simion 2008 reported no statically significant difference between groups (195.32 \pm 71.21 minutes versus $146.94 \pm 70$ minutes) $(P=0.07)$, as well as Rajamani 2007 ( $31.43 \pm 34.12$ versus $39.31 \pm 21.05)(P=0.45)$.

\section{Heart rate, respiratory rate, and blood pressure}

The included studies did not report these outcomes.

\section{Time to feeding after surgery}

The meta-analysis of the two studies that reported this outcome, Rajamani 2007 and Simion 2008, showed a significant difference favouring the intervention group compared with control group (MD $-9.45,95 \% \mathrm{Cl}-17.37$ to -1.53 ; 2 studies; 128 children; $\mathrm{P}=0.02$; $1^{2}=0 \%$ ) (Analysis 2.2). This outcome was downgraded one level to moderate-quality evidence due to few studies with a limited number of children.

\section{Duration of hospitalisation}

None of the included studies reported this outcome.

\section{Infraorbital nerve block versus infiltration of the incision}

Two studies compared infraorbital nerve block with anaesthetic infiltration of the incision (Gaonkar 2004; Prabhu 1999).

\section{Primary outcomes}

\section{Pain measured by valid instruments}

The authors of Gaonkar 2004 stated that postoperative pain was comparable in the first 24 hours in both groups except at 6 hours, where children in the control group had lower pain scores $(P<0.05)$ compared to those in the intervention group (no data provided by the authors). Prabhu 1999 reported that children in the intervention group had significantly lower pain scores $(P<0.05)$ between one to eight hours after the surgery than those in the control group (only graphics data).

\section{Duration of postoperative analgesia}

The included studies did not report this outcome.

\section{Adverse events}

Gaonkar 2004 reported no adverse events attributable to either analgesic technique. Prabhu 1999 did not report this outcome.

\section{Secondary outcomes}

\section{Need for analgesic prescription for pain}

Prabhu 1999 reported that significantly more children required rescue analgesics in the control group than in the intervention group ( $\mathrm{RR} 0.16,95 \% \mathrm{Cl} 0.05$ to $0.51 ; \mathrm{P}=0.002$ ).

\section{Time to first analgesic requirement}

Gaonkar 2004 reported that the time to first analgesic requirement was significantly longer in the intervention compared with the control group (MD 4.92, 95\% Cl 3.84 to 6.00 ; 1 study; 50 children; $\mathrm{P}$ $<0.001)$.

\section{Heart rate, respiratory rate, and blood pressure}

Gaonkar 2004 reported no differences between groups in postoperative heart rate and blood pressure. Prabhu 1999 reported significantly lower heart rates in the intervention group than in the control group throughout the postoperative period, and no differences in respiratory rate and blood pressure.

\section{Time to feeding after surgery}

The included studies did not report this outcome.

\section{Duration of hospitalisation}

The included studies did not report this outcome.

\section{DISCUSSION}

\section{Summary of main results}

Cleft lip is one of the most common craniofacial birth defects and requires surgical correction, which can be performed during the neonatal period or later. A surgical procedure in children requires excellent postoperative analgesia. We identified 11 randomised controlled trials (Ahuja 1994; Delgado 2005; Gaonkar 2004; Nicodemus 1991; Prabhu 1999; Rajamani 2007; Simion 2008; Takmaz 2009; Jindal 2011; Jonnavithula 2007, and eight fulfilled the inclusion criteria for this systematic review (Ahuja 1994; Delgado 2005; Gaonkar 2004; Nicodemus 1991; Prabhu 1999; Rajamani 2007; Simion 2008; Takmaz 2009).

Three studies compared infraorbital nerve block with placebo and measured postoperative pain (Ahuja 1994; Nicodemus 1991; 
Takmaz 2009). These studies showed a significant difference between the groups favouring the intervention group and no adverse events. More supplemental analgesics were required by the children in the placebo group, and the time to first analgesic requirement was significantly longer in the intervention group. These studies did not report duration of analgesia.

Three studies compared infraorbital nerve block and intravenous analgesia (Delgado 2005; Rajamani 2007; Simion 2008). Two of these studies reported that pain in the first hour after surgery was significantly lower in the intervention group (Delgado 2005; Rajamani 2007). The third study reported no differences between groups one hour after surgery (Simion 2008). Duration of postoperative analgesia and adverse events were not reported. Rajamani 2007 reported that more children in the control group required rescue analgesic. The time to first analgesic requirement showed conflicting results in the three studies: in two studies it was not different between the groups (Rajamani 2007; Simion 2008), and in one study it was longer in the intervention group (Delgado 2005). Rajamani 2007 and Simion 2008 showed a significant difference in time to feeding after surgery favouring the intervention group compared with the control group.

Two studies compared infraorbital nerve block with anaesthetic infiltration of the incision (Gaonkar 2004; Prabhu 1999). Gaonkar 2004 reported no differences in pain scores measured during the first 24 hours after surgery between the groups. Prabhu 1999 reported lower pain scores one to eight hours after surgery in the intervention group. Duration of postoperative analgesia and adverse events were not reported. In Prabhu 1999 more children required rescue analgesics in the control group, and in Gaonkar 2004 the intervention group had a significantly longer time to the first analgesic requirement. Gaonkar 2004 reported no differences between groups in postoperative heart rate and blood pressure, while Prabhu 1999 reported significantly lower heart rates in the intervention group.

None of the studies reported duration of hospitalisation.

\section{Overall completeness and applicability of evidence}

There was heterogeneity in the interventions, participant age, duration of follow-up, and outcome measurement tools in the studies included in this review, which made it difficult to analyse them and draw reliable conclusions.

One of the primary outcomes of this review, the duration of analgesia, was only reported by one study, and another important primary outcome, adverse events, was poorly reported. Of the eight included studies, five reported no significant adverse events, and three did not report this outcome. There is low-quality evidence from a small number of studies and children that infraorbital nerve block with lignocaine and bupivacaine may provide effective pain relief compared to placebo and intravenous analgesia. In fact, the two most recent controlled studies identified in our search started from the hypothesis of superiority of the infraorbital nerve block to compare different types of anaesthetic in cleft lip repair surgery (Jindal 2011; Mane 2011).

\section{Quality of the evidence}

Overall, the included studies were of moderate methodological quality at low or unclear risk of bias. The reasons for downgrading the quality of the evidence related to lack of information about randomisation methods and allocation concealment in the studies, very small sample sizes, and heterogeneity of outcome reporting. The quality of all outcomes included in the 'Summary of findings' tables was downgraded two or three levels. The pooled results for the primary outcome pain showed significant statistical heterogeneity, probably because of the different scales used for measurement and other differences mentioned above. This led to further downgrading of the quality of the evidence for this outcome to very low (GRADEpro GDT 2015).

\section{Potential biases in the review process}

We strived to prevent bias in the review process by involving two independent review authors in each step of the review and by performing a comprehensive search with no language restrictions.

\section{Agreements and disagreements with other studies or reviews}

We could not identify other systematic reviews on infraorbital nerve block for postoperative analgesia after cleft lip repair in children. However, the descriptive studies and expert reports on the efficacy of this treatment are consistent with the findings of our review.

\section{AUTHORS' CONCLUSIONS}

\section{Implications for practice}

\section{For children with postoperative pain following cleft lip repair surgery}

Infraorbital nerve block with lignocaine or bupivacaine may reduce postoperative pain compared with placebo (sham block) and intravenous analgesia. This finding is uncertain due to the very small samples sizes and differences in the interventions and outcomes in the included trials (very low-quality evidence). There is a lack of information about adverse events in many studies and the absence of evidence for some outcomes of interest.

\section{For clinicians and policymakers}

There is low- to very low-quality evidence that infraorbital nerve block may be an effective intervention to be routinely adopted in surgery for cleft lip repair in children.

\section{Implications for research}

\section{General}

Further studies, probably multicentre to obtain a larger sample, are needed to consolidate this evidence, and the most appropriate anaesthetic agent as well as the optimal dosage should also be evaluated.

\section{Design}

Double-blind randomised clinical trials with high methodology quality (that is adequate report of randomisation, allocation concealment, blinding, etc.) are needed. Future studies should standardise the observation time and the instruments used to measure outcomes, and stratify children by age group.

\section{Measurement}

The main outcome should be pain measured by validated instruments proper for each age group. The measurements must be made long enough to measure analgesia time and predefined as 
an hourly basis. The parameters to provide rescue analgesia should be described and standardised across studies. Studies should also report the time to feeding, parental satisfaction, and duration of hospitalisation.

\section{ACKN OWLEDGEMENTS}

We would like to acknowledge the support of Anna Erskine, Cochrane Pain, Palliative and Supportive Care (PaPaS) Group Managing Editor and Joanne Abbott, Information Specialist.
Cochrane Review Group funding acknowledgement: The National Institute for Health Research (NIHR) is the largest single funder of the Cochrane PaPaS Group. Disclaimer: The views and opinions expressed therein are those of the authors and do not necessarily reflect those of the NIHR, National Health Service (NHS), or the Department of Health. 


\section{R E F E R E N C E S}

\section{References to studies included in this review}

Ahuja 1994 \{published data only\}

Ahuja S, Datta A, Krishna A, Bhattacharya A. Infra-orbital nerve block for relief of postoperative pain following cleft lip surgery in infants. Anaesthesia 1994;49(5):441-4.

\section{Delgado 2005 \{published data only\}}

Delgado JA, Martínez-Tellería A, Cano ME, Galera J, FernándezValades R, Ruiz-Montes A. Postoperative analgesia for the management of cheiloplasty in the breast-fed baby. Comparative study: bilateral intraoral blockade of the infraorbitary nerve with bupivacaine $0.25 \%$ plus adrenaline versus intravenous analgesia with tramadol [Analgesia postoperatoria en la queiloplastia dellactante. Estudio comparativo: bloqueo infraorbitario intraoral bilateral con bupivacaína $0,25 \%$ con adrenalina vs. analgesia intravenosa con tramadol]. Revista de la Sociedade Española del Dolor 2005;12(4):204-10.

\section{Gaonkar 2004 \{published data only\}}

Gaonkar V, Daftary SR. Comparison of preoperative infraorbital block with peri-incisional infiltration for postoperative pain relief in cleft lip surgeries. Indian Journal of Plastic Surgery 2004;37(2):105-9.

\section{Nicodemus 1991 \{published data only\}}

Nicodemus HF, Ferrer MJ, Cristobal VC, Castro L. Bilateral infraorbital block with $0.5 \%$ bupivacaine as post-operative analgesia following cheiloplasty in children. Scandinavian Journal of Plastic and Reconstructive Surgery and Hand Surgery 1991;25(3):253-7.

\section{Prabhu 1999 \{published data only\}}

Prabhu KPK, Wig J, Grewal S. Bilateral infraorbital nerve block is superior to peri-incisional infiltration for analgesia after repair of cleft lip. Scandinavian Journal of Plastic and Reconstructuve Surgery and Hand Surgery 1999;33(1):83-7.

\section{Rajamani 2007 \{published data only\}}

Rajamani A, Kamat V, Rajavel VP, Murthy J, Hussain SA. A comparison of bilateral infraorbital nerve block with intravenous fentanyl for analgesia following cleft lip repair in children. Paediatric Anaesthesia 2007;17(2):133-9.

\section{Simion 2008 \{published data only\}}

Simion C, Corcoran J, Iyer A, Suresh SA. Postoperative pain control for primary cleft lip repair in infants: is there an advantage in performing peripheral nerve blocks? Paediatric Anaesthesia 2008;18(11):1060-5.

\section{Takmaz 2009 \{published data only\}}

Takmaz SA, Uusal HY, Uysal A, Kocer U, Dikmen B, Baltaci B. Bilateral extraoral, infraorbital nerve block for postoperative pain relief after cleft lip repair in pediatric patients: a randomized, double-blind controlled study. Annals of Plastic Surgery 2009;63(1):59-62.

\section{References to studies excluded from this review}

Grewal 2015 \{published data only\}

Grewal G, Garg K, Grewal A. Bilateral infraorbital nerve block versus intravenous pentazocine: a comparative study on postoperative pain relief following cleft lip surgery. Journal of Clinical and Diagnostic Research 2015;9(5):UC04-06.

\section{Jindal 2011 \{published data only\}}

Jindal P, Khurana G, Dvivedi S, Sharma JP. Intra and postoperative outcome of adding clonidine to bupivacaine in infraorbital nerve block for young children undergoing cleft lip surgery. Saudi Journal of Anaesthesia 2011;5(3):289-94.

\section{Jonnavithula 2007 \{published data only\}}

Jonnavithula N, Durga P, Kulkarni DK, Ramachandran G. Bilateral intra-oral, infra-orbital nerve block for postoperative analgesia following cleft lip repair in paediatric patients: comparison of bupivacaine vs bupivacaine-pethidine combination. Anaesthesia 2007;62(6):581-5.

Mane 2011 \{published data only\}

Mane RS, Sanikop CS, Dhulkhed VK, Gupta T. Comparison of bupivacaine alone and in combination with fentanyl or pethidine for bilateral infraorbital nerve block for postoperative analgesia in paediatric patients for cleft lip repair: a prospective randomized double blind study. Journal of Anaesthesiology Clinical Pharmacology 2011;27(1):23-6.

\section{Additional references}

\section{Arosarena 2007}

Arosarena OA. Cleft lip and palate. Otolaryngologic Clinics of North America 2007;40(1):27-60.

\section{Augsornwan 2008}

Augsornwan D, Pattangtanang P, Pikhunthod K, Surakunprapha P. Postoperative pain in patients with cleft lip and palate in Srinagarind Hospital. Journal of the Medical Association of Thailand 2008;94(Suppl 6):S118-23.

\section{Biazon 2008}

Biazon J, Peniche AC. Retrospective study of postoperative complications in primary lip and palate surgery. Revista da Escola de Enfermagem da USP 2008;42(3):519-25.

\section{Bosenberg 1995}

Bosenberg AT, Kimble FW. Infraorbital nerve block in neonates for cleft lip repair: anatomical study and clinical application. British Journal of Anaesthesia 1995;74(5):506-8.

\section{Dechartres 2013}

Dechartres A, Trinquart L, Boutron I, Ravaud P. Influence of trial sample size on treatment effect estimates: metaepidemiological study. BMJ 2013;346:(f2304).

\section{Deeks 2011}

Deeks JJ, Higgins JPT, Altman DG (editors). Chapter 9: Analysing data and undertaking meta-analyses. In: Higgins JPT, Green 
$\mathrm{S}$ (editors). Cochrane Handbook for Systematic Reviews of Interventions. Version 5.1.0 [updated March 2011]. The Cochrane Collaboration, 2011. Available from www.cochranehandbook.org.

\section{Gagnon 2009}

Gagnon A, Wilson RD, Allen VM, Audibert F, Blight C, Brock JA, et al, Society of Obstetricians and Gynaecologists of Canada. Evaluation of prenatally diagnosed structural congenital anomalies. Journal of Obstetrics and Gynaecology Canada 2009;31(9):875-81.

\section{GRADEpro GDT 2015 [Computer program]}

McMaster University GRADEpro Guideline Development Tool [Software]. Developed by Evidence Prime, Inc. McMaster University, 2015.Available from www.gradepro.org.

\section{Helgadóttir 2000}

Helgadóttir HL. Pain management practices in children after surgery. Journal of Pediatric Nursing 2000;15(5):334-40.

\section{Higgins 2011}

Higgins JPT, Green S (editors). Cochrane Handbook for Systematic Reviews of Interventions. Version 5.1.0 [updated March 2011]. The Cochrane Collaboration, 2011. Available from www.cochrane-handbook.org.

\section{Hudson-Barr 2002}

Hudson-Barr D, Capper-Michel B, Lambert S, Palermo TM, Morbeto K, Lombardo S. Validation of the Pain Assessment in Neonates (PAIN) scale with the Neonatal Infant Pain Scale (NIPS). Neonatal Network 2002;21(6):15-21.

\section{Jadad 1996}

Jadad AR, Moore RA, Carroll D, Jenkinson C, Reynolds DJ, Gavaghan DJ, et al. Assessing the quality of reports of randomized clinical trials: is blinding necessary? Controlled Clinical Trials 1996;17(1):1-12.

\section{Law 2002}

Law RC, Klerk C. Anaesthesia for cleft lip and palate surgery. Update in Anaesthesia 2002;14(9):27-30.

\section{Liberati 2009}

Liberati A, Altman DG, Tetzlaff J, Mulrow C, Gøtzsche PC, loannidiset JP, et al. The PRISMA Statement for reporting systematic reviews and meta-analyses of studies that evaluate health care interventions: explanation and elaboration. Annals of Internal Medicine 2009;151(4):W65-94.

\section{Mathes 2006}

Mathes SJ. Plastic Surgery. 2nd edition. Philadelphia: Elsevier, 2006.

\section{Merkel 1997}

Merkel SI, Voepel-Lewis T, Shayevitz JR, Malviya S. The FLACC: a behavioral scale for scoring postoperative pain in young children. Pediatric Nursing 1997;23(3):293-7.

\section{Mossey 2009}

Mossey PA, Little J, Munger RG, Dixon MJ, Shaw WC. Cleft lip and palate. The Lancet 2009;374(9703):1773-85.

\section{Nüesch 2010}

Nüesch E, Trelle S, Reichenbach S, Rutjes AW, Tschannen B, Altman DG, et al. Small study effects in meta-analyses of osteoarthritis trials: meta-epidemiological study. BMJ 2010;341: (c3515).

\section{RevMan 2014 [Computer program]}

The Nordic Cochrane Centre, The Cochrane Collaboration Review Manager (RevMan). Version 5.3. Copenhagen: The Nordic Cochrane Centre, The Cochrane Collaboration, 2014.

\section{Rodriguez 2001}

Rodriguez MTC, Torres MEM. Cleft lip and palate. General aspects to be found on the primary health care [translated via Google 23 May 2014] [Labio y paladar fisurados: aspectos generales que se deben conocer en la atención primaria de salud]. Revista Cubana de Medicina General Integral 2001;17(4):379-85.

\section{Schünemann 2011}

Schünemann HJ, Oxman AD, Vist GE, Higgins JPT, Deeks JJ, Glasziou P, et al on behalf of the Cochrane Applicability and Recommendations Methods Group. Chapter 11: Presenting results and 'Summary of findings' tables. In: Higgins JPT, Green S (editors). Cochrane Handbook for Systematic Reviews of Interventions Version 5.1.0 [updated March 2011]. The Cochrane Collaboartion, 2011. Available from www.cochranehandbook.org.

\section{Shkoukani 2013}

Shkoukani MA, Chen M, Vong A. Cleft lip - a comprehensive review. Frontiers in Pediatrics 2013 Dec 27 [Epub ahead of print].

\section{Strichartz 1976}

Strichartz G. Molecular mechanisms of nerve block by local anesthetics. Anesthesiology 1976;45(4):721-41.

\section{Sykes 2005}

Sykes JM, Tollefson TT. Management of the cleft lip deformity. Facial Plastic Surgery Clinics of North America 2005;13(1):157-67.

\section{WHO 2004}

World Health Organization. Addressing the global challenges of craniofacial anomalies. Report of WHO Meetings on International Collaborative Research on Craniofacial Anomalies (4th meeting, Geneva, Switzerland). www.who.int/genomics/ publications/CFA\%20Completed\%20text.pdf (accessed 20 May 2014). 
CHARACTERISTICS OF STUDIES

Characteristics of included studies [ordered by study ID]

Ahuja 1994

\section{Study characteristics}

\begin{tabular}{ll}
\hline Study design: prospective, randomised, double-blind, controlled trial \\
Intention-to-treat:not stated \\
Sample size calculation: not stated \\
Setting: single centre. India \\
Follow up: 3 hours
\end{tabular}

\begin{tabular}{ll}
\hline Participants & N $=20$ (45\% male) \\
& Age: 2 to 11 months \\
\hline Interventions & Group 1: $(\mathrm{n}=10)$ extra oral infraorbital nerve block with $1 \mathrm{ml}$ of $1 \%$ lignocaine with adrenaline \\
& Group 2: $(\mathrm{n}=10)$ "sham" block \\
\hline Outcomes & Postoperative pain assessment score (PAS) \\
& - Heart rate \\
& B Reod pressure \\
- Supplemental analgesic requirements \\
\hline Notes & Jadad score: 4 \\
\hline
\end{tabular}

\section{Risk of bias}

\begin{tabular}{|c|c|c|}
\hline Bias & Authors' judgement & Support for judgement \\
\hline $\begin{array}{l}\text { Random sequence genera- } \\
\text { tion (selection bias) }\end{array}$ & Unclear risk & Not stated \\
\hline $\begin{array}{l}\text { Allocation concealment } \\
\text { (selection bias) }\end{array}$ & Unclear risk & Not stated \\
\hline $\begin{array}{l}\text { Blinding of participants } \\
\text { and personnel (perfor- } \\
\text { mance bias) } \\
\text { All outcomes }\end{array}$ & Low risk & $\begin{array}{l}\text { "All patients in control group were given sham blocks at the same site to avoid } \\
\text { observer bias" }\end{array}$ \\
\hline $\begin{array}{l}\text { Blinding of outcome as- } \\
\text { sessment (detection bias) } \\
\text { All outcomes }\end{array}$ & Low risk & $\begin{array}{l}\text { "Observations were made by a single independent observer who was unaware } \\
\text { of the analgesic technique" }\end{array}$ \\
\hline $\begin{array}{l}\text { Incomplete outcome data } \\
\text { (attrition bias) } \\
\text { All outcomes }\end{array}$ & Low risk & No losses \\
\hline $\begin{array}{l}\text { Selective reporting (re- } \\
\text { porting bias) }\end{array}$ & Low risk & The report of the study was free of suggestion of selective outcome reporting \\
\hline
\end{tabular}


Ahuja 1994 (Continued)
Other bias
High risk
Size: sample size less than 50 per treatment arm

Delgado 2005

\section{Study characteristics}

\begin{tabular}{ll}
\hline Study design: prospective, randomised, double-blind, controlled trial \\
Intention-to-treat: not stated \\
Sample size calculation: not stated \\
Setting: single centre. Spain \\
Follow up: 6 hours \\
\hline
\end{tabular}

Participants $\quad \mathrm{N}=25$

Age: 3 to 10 months

Interventions Group 1: $(n=12)$ intraoral infraorbital nerve block with 1 to $2 \mathrm{ml}$ of bupivacaine $0.25 \%$ plus adrenaline was administered and intravenous saline solution instead of intravenous analgesia with tramadol

Group 2: $(n=13)$ saline solution was administered for nerve blockade, instead of bupivacaine, and intravenous tramadol $(1.5 \mathrm{mg} / \mathrm{kg}$ ) was provided

\begin{tabular}{|c|c|c|}
\hline Outcomes & \multicolumn{2}{|c|}{$\begin{array}{l}\text { - Length of analgesia } \\
\text { - Pain intensity - subjective measure by observer with } 0 \text { to } 5 \text { scale } \\
\text { - Discomfort grade - measured by objective scale }\end{array}$} \\
\hline Notes & \multicolumn{2}{|l|}{ Jadad score: 4} \\
\hline \multicolumn{3}{|l|}{ Risk of bias } \\
\hline Bias & Authors' judgement & Support for judgement \\
\hline $\begin{array}{l}\text { Random sequence genera- } \\
\text { tion (selection bias) }\end{array}$ & Unclear risk & Not stated \\
\hline $\begin{array}{l}\text { Allocation concealment } \\
\text { (selection bias) }\end{array}$ & Unclear risk & Not stated \\
\hline $\begin{array}{l}\text { Blinding of participants } \\
\text { and personnel (perfor- } \\
\text { mance bias) } \\
\text { All outcomes }\end{array}$ & Low risk & Double blinded. Saline solution used as control \\
\hline $\begin{array}{l}\text { Blinding of outcome as- } \\
\text { sessment (detection bias) } \\
\text { All outcomes }\end{array}$ & Low risk & Medical staff and nurses were fully unaware of the analgesic technique used \\
\hline $\begin{array}{l}\text { Incomplete outcome data } \\
\text { (attrition bias) } \\
\text { All outcomes }\end{array}$ & Low risk & No losses \\
\hline
\end{tabular}


Delgado 2005 (Continued)

Selective reporting (re- Low risk The report of the study was free of suggestion of selective outcome reporting porting bias)

Other bias

High risk

Size: sample size less than 50 per treatment arm

Gaonkar 2004

\section{Study characteristics}

\begin{tabular}{|c|c|}
\hline \multirow[t]{4}{*}{ Methods } & $\begin{array}{l}\text { Study design: prospective, randomised, double-blind, controlled trial } \\
\text { Intention-to-treat: not stated }\end{array}$ \\
\hline & Sample size calculation: not stated \\
\hline & Setting: single centre. India \\
\hline & Follow up: 36 hours \\
\hline \multirow[t]{2}{*}{ Participants } & $N=50$ \\
\hline & Age: 4 to 72 months \\
\hline \multirow[t]{2}{*}{ Interventions } & $\begin{array}{l}\text { Group 1: }(n=25) \text { extraoral infraorbital nerve block with } 1 \mathrm{ml} \text { bupivacaine } 0.25 \% \text { plus adrenaline was ad- } \\
\text { ministered and saline solution infiltration of the incision }\end{array}$ \\
\hline & $\begin{array}{l}\text { Group 2: }(n=25) \text { saline solution was administered for nerve blockade, and } 1 \mathrm{ml} \text { bupivacaine } 0.25 \% \text { plus } \\
\text { adrenaline was infiltrated in the incision }\end{array}$ \\
\hline Outcomes & $\begin{array}{l}\text { - Postoperative pain relief scoring was measured according to Hanallah's 10-point score } \\
\text { - Time to first analgesic given as a rescue }\end{array}$ \\
\hline Notes & Jadad score: 4 \\
\hline
\end{tabular}

\section{Risk of bias}

\begin{tabular}{lll}
\hline Bias & Authors' judgement & Support for judgement \\
\hline $\begin{array}{l}\text { Random sequence genera- } \\
\text { tion (selection bias) }\end{array}$ & Unclear risk & Not stated \\
\hline $\begin{array}{l}\text { Allocation concealment } \\
\text { (selection bias) }\end{array}$ & Unclear risk & Not stated \\
\hline $\begin{array}{l}\text { Blinding of participants } \\
\text { and personnel (perfor- } \\
\text { mance bias) } \\
\text { All outcomes }\end{array}$ & Low risk & Double blinded. Saline solution used as control \\
\hline $\begin{array}{l}\text { Blinding of outcome as- } \\
\text { sessment (detection bias) } \\
\text { All outcomes }\end{array}$ & Low risk & Double blinded. Saline solution used as control \\
\hline $\begin{array}{l}\text { Incomplete outcome data } \\
\text { (attrition bias) } \\
\text { All outcomes }\end{array}$ & Low risk & No losses \\
\hline
\end{tabular}


Gaonkar 2004 (Continued)

Selective reporting (re- Low risk The report of the study was free of suggestion of selective outcome reporting
porting bias)

Other bias

High risk

Size: sample size less than 50 per treatment arm

Nicodemus 1991

\section{Study characteristics}

\begin{tabular}{|c|c|}
\hline \multirow[t]{4}{*}{ Methods } & $\begin{array}{l}\text { Study design: prospective, randomised, double-blind, controlled trial } \\
\text { Intention-to-treat: not stated }\end{array}$ \\
\hline & Sample size calculation: not stated \\
\hline & Setting: single centre. USA \\
\hline & Follow up: 24 hours \\
\hline \multirow[t]{2}{*}{ Participants } & $\mathrm{N}=60(60 \%$ male $)$ \\
\hline & Age: 2 to 13 years \\
\hline \multirow[t]{2}{*}{ Interventions } & Group 1: $(n=30)$ intraoral infraorbital nerve block with 1 to $1.5 \mathrm{ml}$ bupivacaine $0.5 \%$ plus adrenaline \\
\hline & Group 2: $(n=30)$ saline placebo in the infraorbital area \\
\hline \multirow[t]{4}{*}{ Outcomes } & - Pain reported by the children through visual analogue scale ( 0 to 5 ) \\
\hline & - Pain evaluated by nurses and parents through score (0 to 4$)$ \\
\hline & - Length of analgesia \\
\hline & - Supplemental analgesic requirements \\
\hline Notes & Jadad score: 4 \\
\hline
\end{tabular}

\section{Risk of bias}

\begin{tabular}{|c|c|c|}
\hline Bias & Authors' judgement & Support for judgement \\
\hline $\begin{array}{l}\text { Random sequence genera- } \\
\text { tion (selection bias) }\end{array}$ & Unclear risk & Not stated \\
\hline $\begin{array}{l}\text { Allocation concealment } \\
\text { (selection bias) }\end{array}$ & Unclear risk & Not stated \\
\hline $\begin{array}{l}\text { Blinding of participants } \\
\text { and personnel (perfor- } \\
\text { mance bias) } \\
\text { All outcomes }\end{array}$ & Low risk & $\begin{array}{l}\text { "The anaesthetist who performed the block and the subsequent evaluation, } \\
\text { the nurses and the parents who evaluated the patient's comfort were all kept } \\
\text { unaware of the identity of the solution used for block" }\end{array}$ \\
\hline $\begin{array}{l}\text { Blinding of outcome as- } \\
\text { sessment (detection bias) } \\
\text { All outcomes }\end{array}$ & Low risk & See above \\
\hline
\end{tabular}

Incomplete outcome data Low risk No losses
(attrition bias)

(attrition bias)
All outcomes 
Nicodemus 1991 (Continued)

Selective reporting (re- Low risk The report of the study was free of suggestion of selective outcome reporting porting bias)

Other bias

High risk

Size: sample size less than 50 per treatment arm

Prabhu 1999

\section{Study characteristics}

\begin{tabular}{|c|c|}
\hline \multirow[t]{4}{*}{ Methods } & $\begin{array}{l}\text { Study design: prospective, randomised, double-blind, controlled trial } \\
\text { Intention-to-treat: Not stated }\end{array}$ \\
\hline & Sample size calculation: Not stated \\
\hline & Setting: single centre. India \\
\hline & Follow up: 24 hours \\
\hline \multirow[t]{2}{*}{ Participants } & $\mathrm{N}=30(63.3 \%$ male $)$ \\
\hline & Age: 4 to 20 months \\
\hline \multirow[t]{2}{*}{ Interventions } & $\begin{array}{l}\text { Group 1: }(n=15) \text { extraoral infraorbital nerve block with } 2 \mathrm{ml} \text { bupivacaine } 0.125 \% \text { plus adrenaline and } \\
\text { peri-incisional infiltration with saline solution }\end{array}$ \\
\hline & $\begin{array}{l}\text { Group 2: }(n=15) \text { saline placebo in the infraorbital area and peri-incisional infiltration with } 2 \mathrm{ml} \text { bupiva- } \\
\text { caine } 0.125 \% \text { plus adrenaline }\end{array}$ \\
\hline Outcomes & $\begin{array}{l}\text { - Pain assessed using a 2-point pain relief score consisting of } 10 \text { behavioural variables } \\
\text { - Heart rate, blood pressure, and respiratory rate } \\
\text { - Supplemental analgesic requirements }\end{array}$ \\
\hline Notes & Jadad score: 4 \\
\hline
\end{tabular}

\section{Risk of bias}

\begin{tabular}{lll}
\hline Bias & Authors' judgement & Support for judgement \\
\hline $\begin{array}{l}\text { Random sequence genera- } \\
\text { tion (selection bias) }\end{array}$ & Unclear risk & Not stated \\
\hline $\begin{array}{l}\text { Allocation concealment } \\
\text { (selection bias) }\end{array}$ & Unclear risk & Not stated \\
\hline $\begin{array}{l}\text { Blinding of participants } \\
\text { and personnel (perfor- } \\
\text { mance bias) }\end{array}$ & Low risk & "Both the surgeon and the anaesthetist were handed prefilled syringes and \\
All outcomes & were unaware of the nature of the solution that they were injecting" \\
\hline $\begin{array}{l}\text { Blinding of outcome as- } \\
\text { sessment (detection bias) } \\
\text { All outcomes }\end{array}$ & Low risk & Double-blind study \\
\hline
\end{tabular}

Incomplete outcome data Low risk No losses
(attrition bias)


Prabhu 1999 (Continued)

All outcomes

Selective reporting (re- Low risk The report of the study was free of suggestion of selective outcome reporting
porting bias)

Other bias High risk Size: sample size less than 50 per treatment arm

Rajamani 2007

\section{Study characteristics}

\begin{tabular}{|c|c|}
\hline \multirow[t]{4}{*}{ Methods } & $\begin{array}{l}\text { Study design: prospective, randomised, double-blind, controlled trial } \\
\text { Intention-to-treat: Not stated }\end{array}$ \\
\hline & Sample size calculation: Not stated \\
\hline & Setting: single centre. India \\
\hline & Follow up: 2 hours \\
\hline \multirow[t]{2}{*}{ Participants } & $\mathrm{N}=82(60.9 \%$ male $)$ \\
\hline & Age: 3 months to 10 years \\
\hline \multirow[t]{2}{*}{ Interventions } & $\begin{array}{l}\text { Group 1: }(n=41) \text { extraoral infraorbital nerve block with } 2 \mathrm{ml} \text { of bupivacaine } 0.25 \% \text { was administered } \\
\text { and intravenous saline solution instead of intravenous analgesia }\end{array}$ \\
\hline & $\begin{array}{l}\text { Group 2: ( } n=41 \text { ) saline solution was administered for nerve blockade, instead of bupivacaine, and in- } \\
\text { travenous fentanyl }(2 \mu \mathrm{g} / \mathrm{kg} \text { ) was provided }\end{array}$ \\
\hline Outcomes & $\begin{array}{l}\text { - Pain: measured by Children and Infants Postoperative Pain Scale score } \\
\text { - Supplemental analgesic requirements } \\
\text { - Length of analgesia } \\
\text { - Time to feed }\end{array}$ \\
\hline Notes & Jadad score: 5 \\
\hline
\end{tabular}

\section{Risk of bias}

\begin{tabular}{lll}
\hline Bias & Authors' judgement & Support for judgement \\
\hline $\begin{array}{l}\text { Random sequence genera- } \\
\text { tion (selection bias) }\end{array}$ & Low risk & $\begin{array}{l}\text { The author informed us by email that randomisation was by drawing lots from } \\
\text { a box including folded papers with the } 2 \text { anaesthetic options being pre-written }\end{array}$ \\
\hline $\begin{array}{l}\text { Allocation concealment } \\
\text { (selection bias) }\end{array}$ & Low risk & $\begin{array}{l}\text { The author informed us by email that randomisation was by drawing lots from } \\
\text { a box including folded papers with the } 2 \text { anaesthetic options being pre-written }\end{array}$ \\
\hline $\begin{array}{l}\text { Blinding of participants } \\
\text { and personnel (perfor- } \\
\text { mance bias) } \\
\text { All outcomes }\end{array}$ & Low risk & $\begin{array}{l}\text { "anaesthesiologist (blinded to the analgesic used) assessed the child's airway } \\
\text { reflexes, recovery from anaesthesia, respiratory and cardiovascular status and } \\
\text { operative site bleeding" }\end{array}$ \\
\hline
\end{tabular}

$\begin{array}{ll}\begin{array}{l}\text { Blinding of outcome as- } \\ \text { sessment (detection bias) }\end{array} \quad \text { Low risk } & \text { "child was handed over to the mother, and was monitored by the recovery } \\ \text { room nurse. The nurse was blinded to the analgesia used" }\end{array}$

All outcomes 
Rajamani 2007 (Continued)

Incomplete outcome data Low risk No losses
(attrition bias)

All outcomes

\begin{tabular}{lll}
\hline $\begin{array}{l}\text { Selective reporting (re- } \\
\text { porting bias) }\end{array}$ & Low risk & The report of the study was free of suggestion of selective outcome reporting \\
\hline Other bias & High risk & Size: sample size less than 50 per treatment arm \\
\hline
\end{tabular}

Simion 2008

\section{Study characteristics}

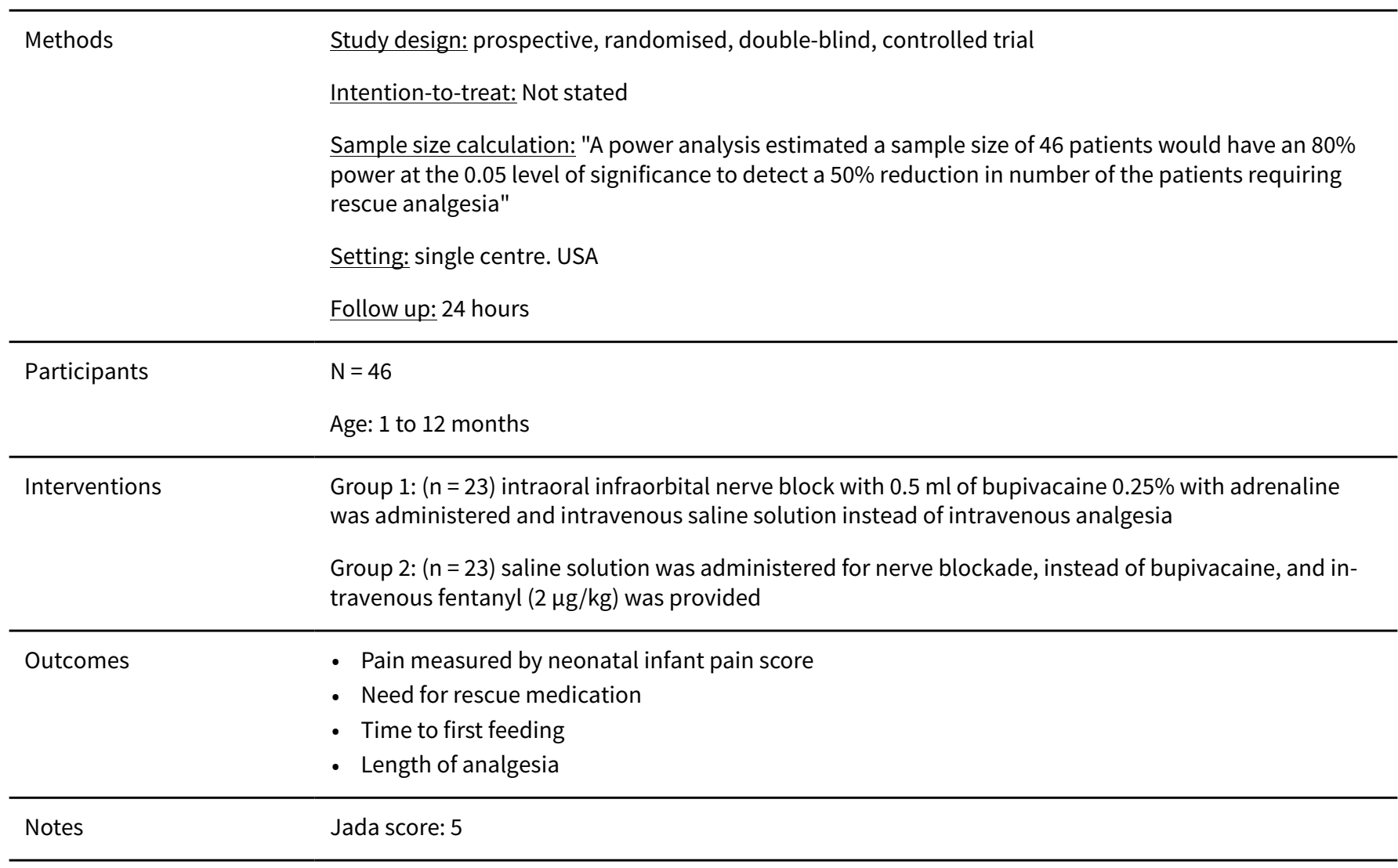

\section{Risk of bias}

\begin{tabular}{|c|c|c|}
\hline Bias & Authors' judgement & Support for judgement \\
\hline $\begin{array}{l}\text { Random sequence genera- } \\
\text { tion (selection bias) }\end{array}$ & Low risk & $\begin{array}{l}\text { "The patients were randomised to one of two groups using a computer gener- } \\
\text { ated randomizations table" }\end{array}$ \\
\hline $\begin{array}{l}\text { Allocation concealment } \\
\text { (selection bias) }\end{array}$ & Unclear risk & Not stated \\
\hline $\begin{array}{l}\text { Blinding of participants } \\
\text { and personnel (perfor- } \\
\text { mance bias) } \\
\text { All outcomes }\end{array}$ & Low risk & $\begin{array}{l}\text { "The patients were transported to the postanaesthesia care unit (PACU) where } \\
\text { a blinded observer evaluated pain and discomfort" }\end{array}$ \\
\hline
\end{tabular}


Simion 2008 (Continued)

Blinding of outcome as- $\quad$ Low risk $\quad$ "Patients were observed by a blinded observer"
sessment (detection bias)

All outcomes

\begin{tabular}{lll}
\hline $\begin{array}{l}\text { Incomplete outcome data } \\
\text { (attrition bias) } \\
\text { All outcomes }\end{array}$ & Low risk & No losses \\
\hline $\begin{array}{l}\text { Selective reporting (re- } \\
\text { porting bias) }\end{array}$ & Low risk & The report of the study was free of suggestion of selective outcome reporting \\
\hline Other bias & High risk & Size: sample size less than 50 per treatment arm \\
\hline
\end{tabular}

Takmaz 2009

\section{Study characteristics}

\begin{tabular}{|c|c|}
\hline \multirow[t]{4}{*}{ Methods } & $\begin{array}{l}\text { Study design: prospective, randomised, double-blind, controlled trial } \\
\text { Intention-to-treat: Not stated }\end{array}$ \\
\hline & $\begin{array}{l}\text { Sample size calculation: "The calculated sample size for a clinical difference of } 4.5 \text { hours between the } \\
\text { groups, at an alpha error of } 5 \% \text { and a beta error of } 90 \% \text {, was } 20 \text { per group" }\end{array}$ \\
\hline & Setting: single centre. Turkey \\
\hline & Follow up: 24 hours \\
\hline Participants & $\mathrm{N}=40(65 \%$ male $)$ \\
\hline Interventions & $\begin{array}{l}\text { Group 1: }(n=20) \text { extraoral infraorbital nerve block with } 1.5 \mathrm{ml} \text { of bupivacaine } 0.25 \% \text { with adrenaline } \\
\text { Group 2: }(n=20) \text { "sham" block with saline solution }\end{array}$ \\
\hline Outcomes & $\begin{array}{l}\text { - Pain measured by the Face, Legs, Activity, Cry, Consolability (FLACC) Scale } \\
\text { - Heart rate, blood pressure, and respiratory rate } \\
\text { - Time to first analgesic requirement } \\
\text { - Rescue analgesia requirement } \\
\text { - Parent satisfaction } \\
\text { - Adverse effect }\end{array}$ \\
\hline Notes & Jadad score: 5 \\
\hline
\end{tabular}

\section{Risk of bias}

\begin{tabular}{lll}
\hline Bias & Authors' judgement & Support for judgement \\
\hline $\begin{array}{l}\text { Random sequence genera- } \\
\text { tion (selection bias) }\end{array}$ & Low risk & Computer-generated random number table \\
\hline $\begin{array}{l}\text { Allocation concealment } \\
\text { (selection bias) }\end{array}$ & Unclear risk & Not stated \\
\hline $\begin{array}{l}\text { Blinding of participants } \\
\text { and personnel (perfor- } \\
\text { mance bias) }\end{array}$ & Low risk & $\begin{array}{l}\text { "In all patients, the nerve block was performed by the anaesthetist who was } \\
\text { unaware of the content of the solution" }\end{array}$ \\
\hline
\end{tabular}


Takmaz 2009 (Continued)

All outcomes

\begin{tabular}{|c|c|c|}
\hline $\begin{array}{l}\text { Blinding of outcome as- } \\
\text { sessment (detection bias) } \\
\text { All outcomes }\end{array}$ & Low risk & $\begin{array}{l}\text { "Postoperative assessment was performed by an investigator blinded to the } \\
\text { patient's group" }\end{array}$ \\
\hline $\begin{array}{l}\text { Incomplete outcome data } \\
\text { (attrition bias) } \\
\text { All outcomes }\end{array}$ & Low risk & No losses \\
\hline $\begin{array}{l}\text { Selective reporting (re- } \\
\text { porting bias) }\end{array}$ & Low risk & The report of the study was free of suggestion of selective outcome reporting \\
\hline Other bias & High risk & Size: sample size less than 50 per treatment arm \\
\hline
\end{tabular}

Characteristics of excluded studies [ordered by study ID]

\begin{tabular}{ll}
\hline Study & Reason for exclusion \\
\hline Grewal 2015 & Not randomised \\
\hline Jindal 2011 & Both groups received infraorbital block. The study compared addition of clonidine to bupivacaine \\
\hline Jonnavithula 2007 & Both groups received infraorbital block. The study compared addition of pethidine to bupivacaine \\
\hline Mane 2011 & $\begin{array}{l}\text { Both groups received infraorbital block. The study compared addition of pethidine or fentanyl to } \\
\text { bupivacaine }\end{array}$ \\
\hline
\end{tabular}

DATA AND ANALYSES

Comparison 1. Infraorbital nerve block vs placebo

\begin{tabular}{lllll}
\hline Outcome or subgroup title & $\begin{array}{l}\text { No. of } \\
\text { studies }\end{array}$ & $\begin{array}{l}\text { No. of } \\
\text { partici- } \\
\text { pants }\end{array}$ & Statistical method & Effect size \\
\hline 1.1 Pain & 3 & 120 & Std. Mean Difference (IV, Random, 95\% Cl) & $-3.54[-6.13,-0.95]$ \\
\hline $\begin{array}{l}1.2 \text { Supplemental analgesic re- } \\
\text { quirements }\end{array}$ & 3 & 120 & Risk Ratio (M-H, Fixed, 95\% Cl) & $0.05[0.01,0.18]$ \\
\hline
\end{tabular}


Analysis 1.1. Comparison 1: Infraorbital nerve block vs placebo, Outcome 1: Pain

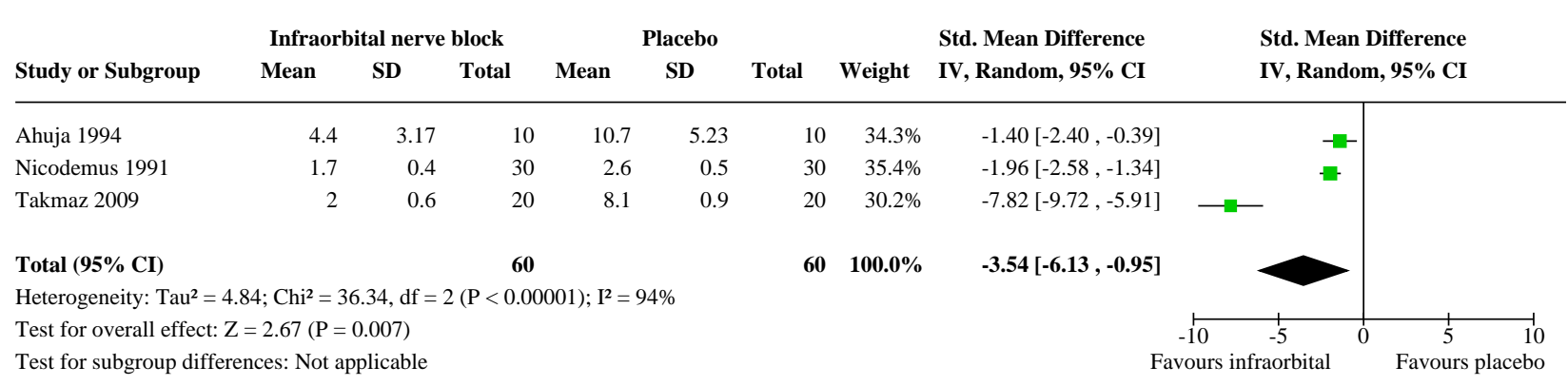

Analysis 1.2. Comparison 1: Infraorbital nerve block vs placebo, Outcome 2: Supplemental analgesic requirements

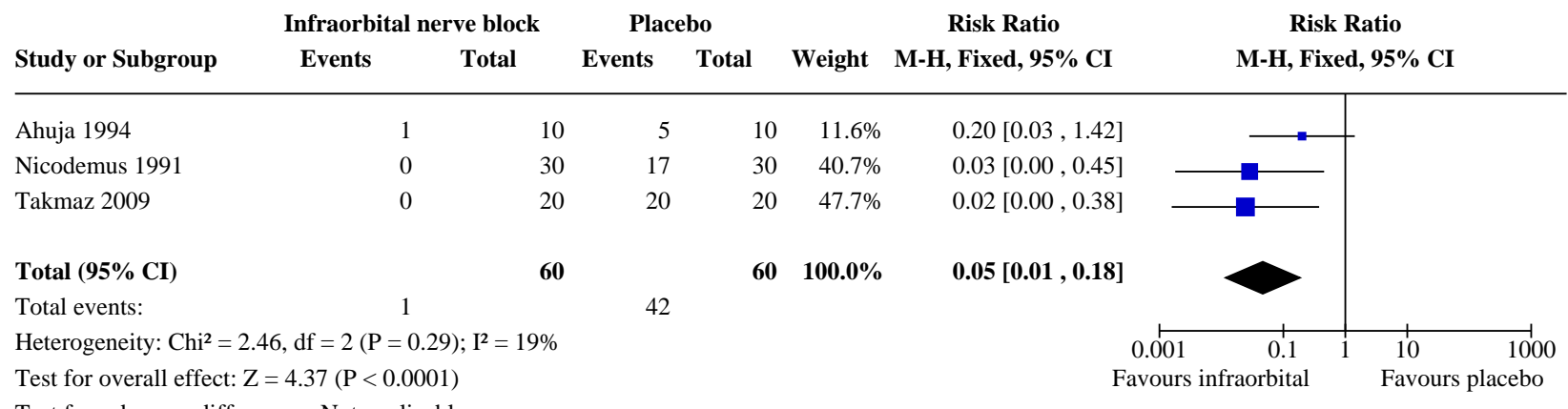

\section{Comparison 2. Infraorbital nerve block vs intravenous analgesia}

\begin{tabular}{lllll}
\hline $\begin{array}{l}\text { Outcome or subgroup ti- } \\
\text { tle }\end{array}$ & $\begin{array}{l}\text { No. of } \\
\text { studies }\end{array}$ & $\begin{array}{l}\text { No. of par- } \\
\text { ticipants }\end{array}$ & Statistical method & Effect size \\
\hline 2.1 Pain & 2 & 107 & Std. Mean Difference (IV, Random, 95\% Cl) & $-1.50[-2.40,-0.60]$ \\
\hline 2.2 Time to feeding & 2 & 128 & Mean Difference (IV, Fixed, 95\% Cl) & $-9.45[-17.37,-1.53]$ \\
\hline
\end{tabular}

Analysis 2.1. Comparison 2: Infraorbital nerve block vs intravenous analgesia, Outcome 1: Pain

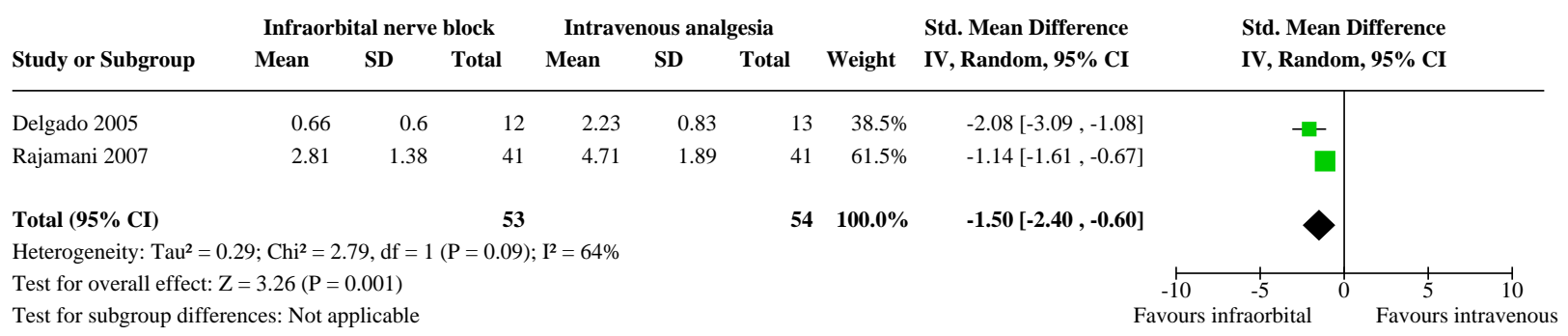


Analysis 2.2. Comparison 2: Infraorbital nerve block vs intravenous analgesia, Outcome 2: Time to feeding

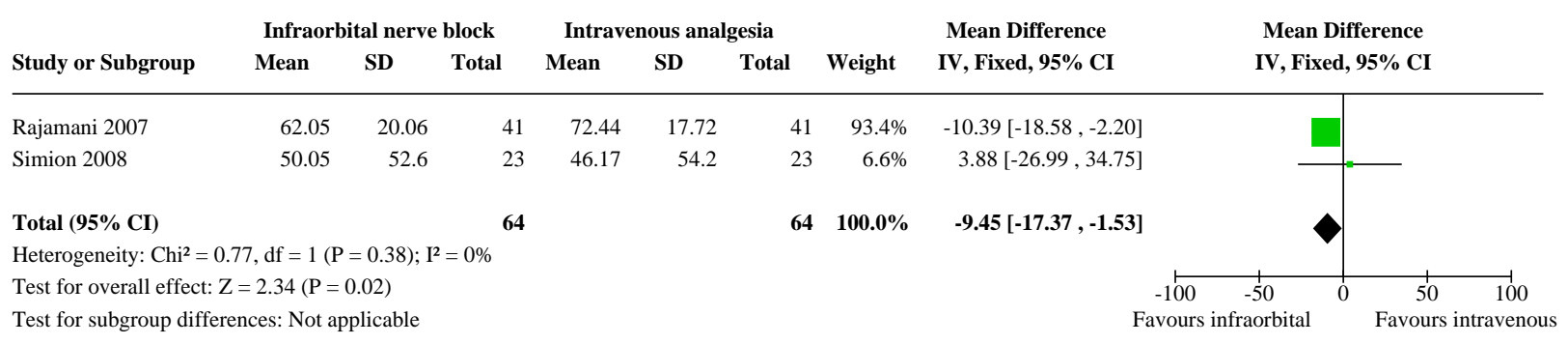

\section{APPENDICES}

\section{Appendix 1. MEDLINE search strategy}

1. Cleft Lip/

2. cheiloschisis.tw.

3. (cleft lip* or harelip*).tw.

4. or $/ 1-3$

5. Pain, Postoperative/

6. ((postoperative adj4 pain ${ }^{\star}$ ) or (post-operative adj4 pain*) or post-operative-pain ${ }^{\star}$ or (post ${ }^{\star}$ adj4 pain ${ }^{\star}$ ) or (postoperative adj4 analgesi ${ }^{\star}$ ) or (post-operative adj4 analgesi*) or "post-operative analgesi*").mp.

7. ((post-surgical adj4 pain*) or ("post surgical" adj4 pain*) or (post-surgery adj4 pain*)).mp.

8. ("pain-relief after surg*" or "pain following surg*" or "pain control after").mp.

9. (("post surg*" or post-surg*) and (pain* or discomfort)).mp.

10. ((pain* adj4 "after surg*") or (pain* adj4 "after operat" ) or (pain* adj4 "follow* operat*") or (pain* adj4 "follow* surg*")).mp.

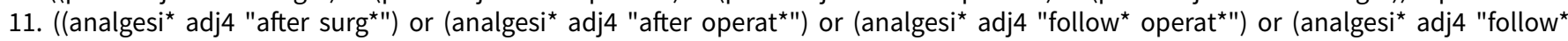
surg*")).mp.

12. exp Surgical Procedures, Operative/

13. or $/ 5-12$

14. Nerve Block/

15. Infra-orbital nerve block. tw.

16. Infraorbital nerve block .tw.

17. Anesthetics, Local/

18. nerve block ${ }^{*}$. tw.

19. or/14-18

20. 4 and 13 and 19

\section{Appendix 2. EMBASE search strategy}

1 Cleft Lip/ (12152)

2 cheiloschisis.tw. (32)

3 (cleft lip* or harelip*).tw. (10813)

4 or/1-3 (15302)

5 Pain, Postoperative/ (41904)

6 ((postoperative adj4 pain ${ }^{\star}$ ) or (post-operative adj4 pain ${ }^{\star}$ ) or post-operative-pain ${ }^{\star}$ or (post ${ }^{\star}$ adj4 pain ${ }^{\star}$ ) or (postoperative adj4 analgesi ${ }^{\star}$ ) or (post-operative adj4 analgesi*) or "post-operative analgesi $\left.{ }^{\star} "\right) . m p . ~(84681)$

7 ((post-surgical adj4 pain*) or ("post surgical" adj4 pain*) or (post-surgery adj4 pain*)).mp. (709)

8 ("pain-relief after surg*" or "pain following surg*" or "pain control after").mp. (803)

9 (("post surg*" or post-surg*) and (pain* or discomfort)).mp. (2682)

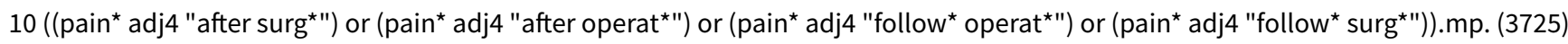


11 ((analgesi* adj4 "after surg*") or (analgesi* adj4 "after operat") or (analgesi* adj4 "follow* operat" ${ }^{\star}$ ) or (analgesi* adj4 "follow" surg*")).mp. (756)

12 exp Surgical Procedures, Operative/ (3376669)

13 or/5-12 (3400440)

14 Nerve Block/ (20534)

15 Infra-orbital nerve block*.tw. (10)

16 Infraorbital nerve block*.tw. (71)

17 Anesthetics, Local/ (23801)

18 nerve block ${ }^{\star} . t w . ~(10053)$

19 or/14-18 (43663)

204 and 13 and 19 (27)

\section{Appendix 3. LILACS search strategy}

\section{\#1 AO \#3}

\#4 MH:"Fenda Labial" OR (Fissura Labial) OR (Labio Leporino) OR (FENDA LABIAL) OR (cleft lip) OR MH:C07.465.409.225\$ OR $\mathrm{MH}: C 07.465 .525 .164 \$$ OR MH:C07.650.525.164\$ OR MH:C16.131.850.525.164\$ OR HARELIP\$ OR CHEILOSCHISIS

\#5 AO \#12

\#13 (MH:"Dor Pós-Operatória" OR (DOR POS OPERATORIA) OR (Dolor Postoperatorio) OR (Pain\$ Postoperative) OR MH:C23.550.767.700\$ OR MH:C23.888.646.530\$ OR (post-operative analgesi\$) OR (postoperative analgesi\$) OR (post surgical pain\$) OR (post surgery pain\$) OR (pain relief after surg\$) OR (pain following surg\$) OR (pain control after) OR ((post surg\$) and (pain\$ or discomfort))) OR MH:"Procedimentos Cirúrgicos Operatórios" OR (Procedimentos Cirúrgicos Operatórios) OR (Procedimientos Quirúrgicos Operativos) OR (Surgical Procedures Operative) OR (Intervenção Cirúrgica) OR (Operação Cirúrgica) OR (Operações Cirúrgicas) OR (Procedimento Cirúrgico) OR (Procedimentos Cirúrgicos) OR MH:E04\$ OR MH:VS3.003.001.006.002\$

$\# 14 \mathrm{AO} \# 18$

\#19 MH:"Bloqueio Nervoso" OR (Bloqueo Nervioso) OR (Nerve Block) OR (BLOQUEIO NERVOSO) OR MH:E03.155.086.711\$ OR MH:E04.525.210.550\$ OR (Infraorbital nerve block\$) OR MH:"Anestésicos Locais" OR (Anestésico\$ Loca\$) OR (Anestésicos Bloqueadores de Condução) OR (Anestésicos Locales) OR (Anesthetics Local) OR MH:D27.505.696.277.100.200\$ OR MH:D27.505.696.663.850.025\$ OR $\mathrm{MH}: \mathrm{D} 27.505 .954 .427 .210 .100 .200 \$$

\#20 \#4 AND \#13 AND \#19

\section{Appendix 4. CENTRAL search strategy}

\section{\#1 MESH DESCRIPTOR Cleft Lip EXPLODE ALL TREES 119}

\#2 cheiloschisis:TI,AB,KY 0

\#3 ((cleft lip* or harelip*)):TI,AB,KY 203

\#4 \#1 OR \#2 OR \#3 203

\#5 MESH DESCRIPTOR Nerve Block 2351

\#6 (Infra-orbital nerve block*):TI,AB,KY 4

\#7 ( Infraorbital nerve block*):TI,AB,KY 16

\#8 MESH DESCRIPTOR Anesthetics, Local 5785

\#9 (nerve block $\left.{ }^{\star}\right): T I, A B, K Y 3436$

\#10 \#5 OR \#6 OR \#7 OR \#8 OR \#9 7867 
\#11 (((post-surgical adj4 pain*) or ("post surgical" adj4 pain*) or (post-surgery adj4 pain*))):TI,AB,KY 83

\#12 (((postoperative adj4 pain $\left.{ }^{\star}\right)$ or (post-operative adj4 pain $\left.{ }^{\star}\right)$ or post-operative-pain* or (post ${ }^{\star}$ adj4 pain $\left.{ }^{\star}\right)$ or (postoperative adj4 analgesi $\left.{ }^{\star}\right)$ or (post-operative adj4 analgesi ${ }^{\star}$ ) or "post-operative analgesi*")):TI,AB,KY 13980

\#13 (("pain-relief after surg*" or "pain following surg*" or "pain control after")):TI,AB,KY 275

\#14 ((("post surg*" or post-surg*) and (pain* or discomfort))):TI,AB,KY 283

\#15 (((pain* adj4 "after surg*") or (pain* adj4 "after operat*") or (pain* adj4 "follow* operat*") or (pain* adj4 "follow* surg*"))):TI,AB,KY 659 \#16 ( ((analgesi* adj4 "after surg*") or (analgesi* adj4 "after operat*") or (analgesi* adj4 "follow* operat*") or (analgesi* adj4 "follow* surg*"))):TI,AB,KY 276

\#17 MESH DESCRIPTOR Pain, Postoperative EXPLODE ALL TREES 9121

\#18 MESH DESCRIPTOR Surgical Procedures, Operative EXPLODE ALL TREES 83773

\#19 \#11 OR \#12 OR \#13 OR \#14 OR \#15 OR \#16 OR \#17 OR \#18 91808

\#20 \#4 AND \#10 AND \#19 11

WHAT'S NEW

\begin{tabular}{lll}
\hline Date & Event & Description \\
\hline 22 June 2020 & Review declared as stable & See Published notes. \\
\hline
\end{tabular}

\section{H I S T O R Y}

Protocol first published: Issue 5, 2014

Review first published: Issue 4, 2016

\begin{tabular}{lll}
\hline Date & Event & Description \\
\hline 10 October 2019 & Amended & Amended terminology in the Plain Language Summary. \\
\hline 20 February 2018 & Review declared as stable & See Published notes \\
\hline
\end{tabular}

CONTRIBUTIONS OF AUTHORS

\begin{tabular}{ll}
\hline Protocol stage: draft the protocol & EMKS, GF, MRT \\
\hline Review stage: select which trials to include & GF, EH, EMKS \\
\hline Review stage: extract data from trials & GF, EH \\
\hline Review stage: enter data into RevMan & GF, EH \\
\hline Review stage: carry out the analysis & GF, EMKS \\
\hline Review stage: interpret the analysis & GF, EMKS, MRT \\
\hline Review stage: draft the final review & GF, EMKS, MRT
\end{tabular}

Infraorbital nerve block for postoperative pain following cleft lip repair in children (Review) 


\section{DECLARATIONS OF INTEREST}

Gustavo Feriani: none known.

Eric Hatanaka: none known.

Maria R Torloni: none known.

Edina MK da Silva: none known.

\section{DIFFERENCES BETWEEN PROTOCOLANDREVIEW}

It was not possible to analyse time-to-event data with method of survival analysis due to lack of adequate data in the included studies.

One study included children up to 13 years of age. Although our review had established 10 years of age as a limit, we decided not to exclude this last study because it likely included few children over this age.

\section{NOTES}

\section{Assessed for updating in 2018}

A restricted search in February 2018 did not identify any potentially relevant studies likely to change the conclusions. Therefore, this review has now been stabilised following discussion with the authors and editors. The review will be re-assessed for updating in early 2020 . If appropriate, we will update the review before this date if new evidence likely to change the conclusions is published, or if standards change substantially which necessitate major revisions.

\section{Assessed for updating in 2020}

A restricted search in February 2020 did not identify any potentially relevant studies likely to change the conclusions. Therefore, this review has now been stabilised following discussion with the authors and editors. The review will be re-assessed for updating in five years. If appropriate, we will update the review earlier if new evidence likely to change the conclusions is published, or if standards change substantially which necessitate major revisions.

\section{N DEX TERMS}

\section{Medical Subject Headings (MeSH)}

Anesthesia, Local; Bupivacaine; Cleft Lip [ ${ }^{\star}$ surgery]; Lidocaine; Nerve Block [ ${ }^{\star}$ methods]; Orbit; Pain, Postoperative [ ${ }^{\star}$ drug therapy]; Randomized Controlled Trials as Topic

\section{MeSH check words}

Adolescent; Child; Child, Preschool; Female; Humans; Infant; Male 